\title{
Carbon isotope stratigraphy of the basal Zechstein (Lopingian) strata in Northern Poland and its global correlation
}

\author{
Tadeusz Marek PERYT, Tomasz DURAKIEWICZ, Maciej J. KOTARBA, \\ Sławomir OSZCZEPALSKI and Danuta PERYT
}

Peryt T. M., Durakiewicz T., Kotarba M. J., Oszczepalski S. and Peryt D. (2012) - Carbon isotope stratigraphy of the basal Zechstein (Lopingian) strata in Northern Poland. Geol. Quart., 56 (2): 285-298, doi: 10.7306/gq.1022

\begin{abstract}
The Kupferschiefer (T1) records a period of basin-wide euxinic conditions, and is thus considered an excellent time-marker in the Zechstein (Lopingian) basin. Previous studies indicated that both the Kupferschiefer and Marl Slate and the overlying Zechstein Limestone (Magnesian Limestone) show remarkable changes in carbon isotopic composition towards higher ${ }^{13} \mathrm{C}_{\text {carb }}$ values. We have examined the Kupferschiefer of the Zdrada IG 8 borehole that has recently been studied in detail by Pašava et al. (2010) aiming to use the carbon isotope data from the basal Zechstein for stratigraphic correlation of the Zechstein basin with the global isotopic curve for Late

Permian. The $\delta^{13} \mathrm{C}$ values in the Zdrada IG 8 change from $+0.7 \%$ at the Kupferschiefer base to $+5.4 \%$ in its middle part, then decrease to $+1.7 \%$ at the Kupferschiefer top and next rapidly increase to $+3.5 \%$ (in the lowest part of the Zechstein Limestone) and finally to $+5.1 \%$ o $(0.5 \mathrm{~m}$ above $)$. This increasing trend continues into the Zechstein Limestone; all subsequent Zechstein marine carbonates show highly positive $\delta^{13} \mathrm{C}$ values. The $\delta^{13} \mathrm{C}$ curve that best shows the Zechstein base may lie near a sequence boundary in the upper Guadalupian of South China that postdates the mid-Guadalupian extinction, but the early Wuchiapingian conodonts reported from the basal Zechstein deposits elsewhere exclude such an interpretation. The increase recorded in the interval from the Kupferschiefer to the Main Dolomite fits well the increase of the $\delta^{13} \mathrm{C}$ values observed after Isotope Event 0 (some $258 \mathrm{Ma}$ ) of the isotopic curve for the Late Permian, although the increase in the Zdrada IG 8 is clearly more significant than that of the global $\delta^{13} \mathrm{C}$ curve. In turn, the subsequent slight fall that accelerated after Isotope Event 1 fits the more significant fall in the Platy Dolomite.
\end{abstract}

Tadeusz M. Peryt and Stawomir Oszczepalski, Polish Geological Institute - National Research Institute, Rakowiecka 4, 00-975 Warszawa, Poland, e-mails: tadeusz.peryt@pgi.gov.pl, slawomir.oszczepalski@pgi.gov.pl; Tomasz Durakiewicz,Los Alamos National Laboratory, MPA-10 Group, Los Alamos, NM87545,USA, e-mail:tomasz@lanl.gov: Maciej J. Kotarba, Facultyof Geology, Geophysics and Environmental Protection, AGH University of Science and Technology, Mickiewicza 30, 30-059 Kraków, Poland, e-mail: kotarba@agh.edu.pl; Danuta Peryt, Institute of Paleobiology, Polish Academy of Sciences, Twarda 51/55, 00-818 Warszawa, Poland, e-mail:d.peryt@twarda.pan.pl (received: May 27, 2011; accepted: February 8, 2012; first published online: May 14, 2012).

Key words: upper Permian, Zechstein, Kupferschiefer, Carbon Isotope Stratigraphy.

\section{INTRODUCTION}

Global C-isotope profiles have proved to be effective in Permian chemostratigraphic correlations particularly in those sedimentary sequences that lack reliable biostratigraphic time markers. Carbon-isotope excursions are recognized in a wide range of marine and continental deposits; they represent major perturbations of the global carbon cycle and are often global events (e.g., Metcalfe et al., 2009; Cao et al., 2010; Bond et al., 2010; Korte and Kozur, 2010; Richoz et al., 2010), although changes in the $\delta^{13} \mathrm{C}$ of carbonate rocks of epeiric seas might not be related to variations in the global organic carbon cycle (e.g., Swart, 2008). Regional stratigraphic correlation within the up- per Permian Zechstein of central and north-west Europe is relatively straightforward since sedimentation throughout the area followed the classical model of cyclic chemical precipitation in a giant saline basin. At its base, the Zechstein contains one of the prime correlation markers in NW European stratigraphy, the Kupferschiefer (= Marl Slate, T1; Fig. 1). This unit records a period of basin-wide euxinic conditions, and can thus be considered an excellent time-marker. The Kupferschiefer is followed by the Zechstein Limestone (Ca1; Fig. 1) that contains the most diverse fauna in the Southern Permian Basin (e.g., Suveizdis, 1975; Hollingworth and Pettigrew, 1988; Wagner, 2001), but the correlation of Zechstein sequences with global standard stages by means of faunal evidence is difficult because of the lack of index fossils, and is still under debate. Rare cono- 


\begin{tabular}{|c|c|c|c|}
\hline Cycle & Unit & Thickness [m] & $\delta^{13} \mathrm{C}$ record \\
\hline PZ3 & Platy Dolomite Ca3 & 20 & 3 \\
\hline \multirow{4}{*}{ PZ2 } & Basal Anhydrite A2 & 20 & \\
\hline & Main Dolomite $\mathrm{Ca} 2$ & 20 & \\
\hline & Upper Anhydrite A1g & 25 & \\
\hline & Oldest Halite $\mathrm{Na} 1$ & $80-200$ & \\
\hline \multirow[t]{3}{*}{ PZ1 } & Lower Anhydrite A1d & $35-175$ & \\
\hline & Zechstein Limestone Ca1 & 10 & 隹 \\
\hline & Kupferschiefer T1 & 0.7 & 6 \\
\hline
\end{tabular}

Fig. 1. Zechstein stratigraphy in the Zdrada area (after Peryt et al., 1998) and the $\delta^{13} \mathrm{C}$ record in the Kupferschiefer (this paper, generalized) and the Zechstein carbonate units

Zechstein Limestone of the Zdrada IG 8 borehole after Peryt and Peryt (2012): solid line - real $\delta^{13} \mathrm{C}$ curve, dashed line - generalized $\delta^{13} \mathrm{C}$ curve; Main Dolomite of the Zdrada IG 4 borehole after Peryt and Magaritz (1990) solid line; Platy Dolomite of the Zdrada IG 3 borehole after Peryt and Scholle (1996); the Main Dolomite and Platy Dolomite generalized $\delta^{13} \mathrm{C}$ curves for the Puck Bay region (after Peryt and Magaritz, 1990; Peryt and Scholle, 1996) are shown by dashed line

donts recorded in the basal Zechstein indicate its early (but not earliest) Lopingian age (Korte et al., 2005, with references therein; Legler and Schneider, 2008).

The basal Zechstein deposits show remarkable changes in carbon isotopic composition towards higher $\delta^{13} \mathrm{C}_{\text {carb }}$ values
(Magaritz et al., 1981; Magaritz and Turner, 1982). In turn, all subsequent Zechstein marine carbonates show highly positive $\delta^{13} \mathrm{C}$ values (e.g., Clark, 1980; Margaritz and Schulze, 1980; Magaritz et al., 1981; Botz and Müller, 1987; Huttel, 1989; Peryt and Magaritz, 1990; Peryt and Scholle, 1996). Słowakiewicz et al. (2009) used published data from the Polish Kupferschiefer (Bechtel et al., 2002) and the Zechstein Limestone (Magaritz and Peryt, 1994) to conclude that the base of the Zechstein is equivalent to the Guadalupian/Lopingian boundary, and should be shifted down to 260.4 Ma (Słowakiewicz et al., 2009; Wagner, 2009). However, earlier published data indicate a rise in $\delta^{13} \mathrm{C}$ values at the base of the Zechstein so it is unclear why they were regarded by Słowakiewicz et al. (2009) as “...$\delta^{13} \mathrm{C}_{\text {carb }}$ negative shift..." (Kamura event - e.g., Isozaki et al., 2007). In addition, their conclusions ignored the previous detailed biostratigraphical considerations indicating that the base of Zechstein is not equivalent to the Guadalupian/Lopingian boundary but instead is younger and of Wuchiapingian age (e.g., Korte et al., 2005, fig. 2) and also ignored magnetostratigraphic evidence (Menning, 2001).

In this paper, we report new data on the carbon and oxygen isotopic composition of calcite in the basal Zechstein deposits in the Zdrada IG 8 borehole located in Northern Poland (Fig. 2). This particular area was located some $70 \mathrm{~km}$ from the palaeo-shoreline and more than $50 \mathrm{~km}$ from the seaward margin of the carbonate platform during Zechstein

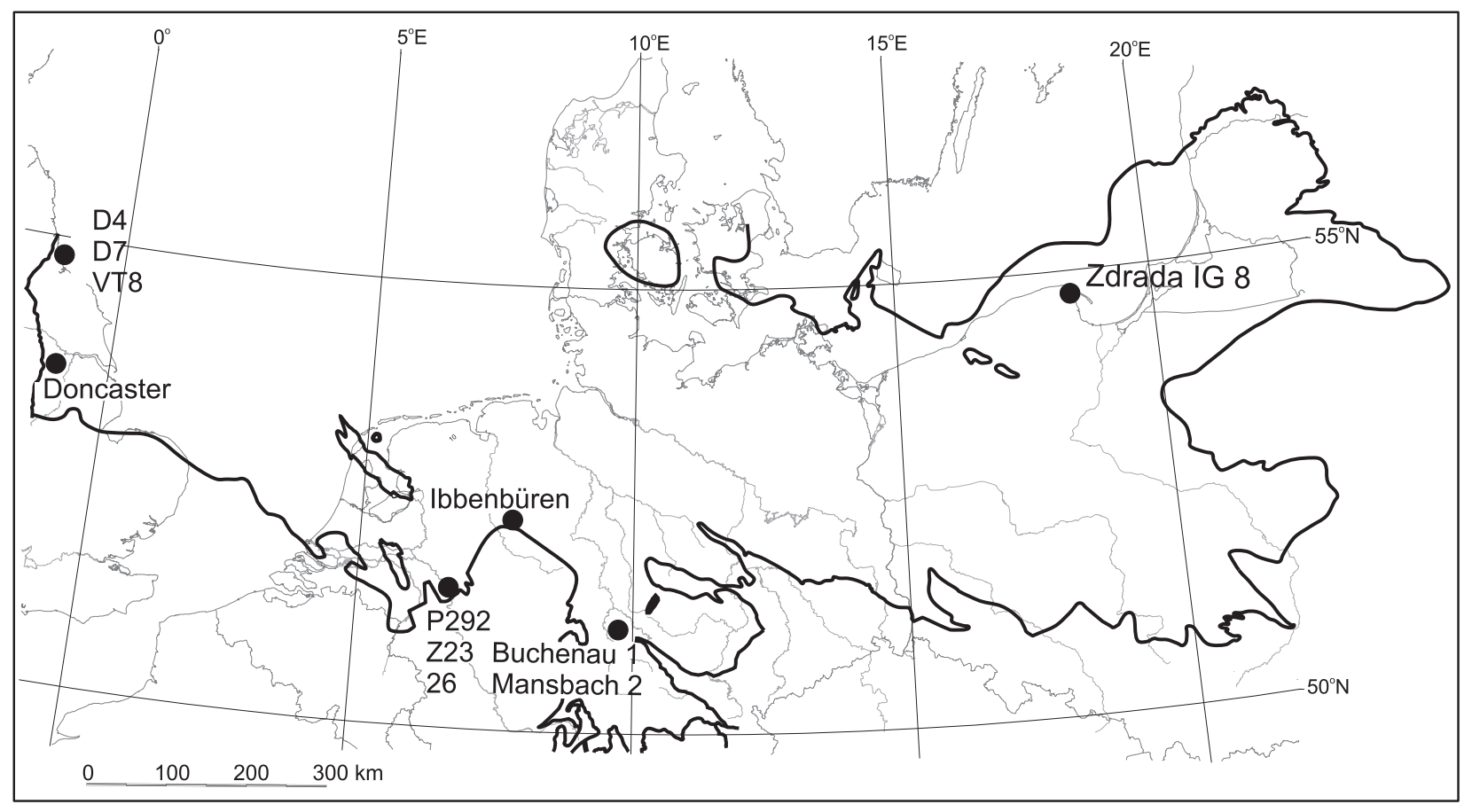

Fig. 2. Location of the Zdrada IG 8 borehole as well as other boreholes discussed in the text; thick solid line shows present limit of the Zechstein Limestone (after Peryt et al., 2010a)

The offshore boreholes D7 and VT8 are located ca. $4 \mathrm{~km}$ NEE of Seaham, and D4 ca. $7 \mathrm{~km} \mathrm{NEE} \mathrm{of} \mathrm{Seaham} \mathrm{(see} \mathrm{Smith,} \mathrm{1994,} \mathrm{fig.} 3$ for detailed location); location of boreholes in Germany after Marowsky (1969), Magaritz et al. (1981) and Bechtel and Püttmann (1997) 
Limestone sedimentation (Peryt et al., 2010a). The Kupferschiefer strata of the Zdrada IG 8 borehole were recently characterized by Pašava et al. (2010) based on study of six samples and we have used the same sample set (plus eight additional samples) in our study. We also discuss the potential of carbon isotope data from the basal Zechstein of the Zdrada IG 8 borehole for stratigraphic correlation of the Zechstein base with the global isotopic curve for the Late Permian.

\section{GEOLOGICAL SETTING}

The Zechstein depositional cyclicity and the onset of the Zechstein basin resulted from a combination of tectonic events and climatic fluctuations, rather than being a direct result of the eustasy ( $c f$. Ross and Ross, 1995). The Zechstein sea was formed virtually instantaneously when the Boreal Ocean broke into and flooded a chain of sub-sea level inland drainage basins (Smith, 1979). At the time of transgression, the Puck Bay area (with the Zdrada IG 8 borehole) was a peneplain, gently dipping toward the Mid-Polish Basin. The Kupferschiefer occurs across almost the entire area except for local erosional elevations that became loci of sedimentation not earlier than during the later part of the Zechstein Limestone which here overlies Silurian deposits. Previous studies (Oszczepalski and Rydzewski, 1987; Oszczepalski, 1989) distinguished three microlithofacies (termed a, b and c) in the Kupferschiefer ba$\sin$. Microlithofacies (a) corresponds to lithotype 1 occurring in the Marl Slate (Turner and Magaritz, 1986). Microlithofacies (b), and microlithofacies (c) have no counterparts in the Marl Slate although microlithofacies (c) shows some similarity to lithotype 1 of Turner and Magaritz (1986). Microlithofacies (b) commonly occurs across almost the entire Kupferschiefer basin (Oszczepalski and Rydzewski, 1987).

In the Zdrada IG 8 borehole the Kupferschiefer is $0.74 \mathrm{~m}$ thick and consists, as already characterized by Pašava et al. (2010), of lower fissile and laminated black clay shales (microlithofacies a, Fig. 3) and upper platy, laminated dark gray calcareous shales (microlithofacies b, Fig. 3) intercalated with organic-rich shale with fine discrete clay and carbonate laminae and lenticular laminae composed of fine-grained terrigenous material (microlithofacies c, Fig. 3). In addition, in the upper part gray streaky marlstones occur (Fig. 3; Pašava et al., 2010). Laminated black clayey shales are rich in organic matter (9.4-10.3 wt.\% $\mathrm{C}_{\text {org }}$ ) and clay material (mostly illite), displaying poorly developed alternations of organic and clay laminae; framboidal pyrite abounds (2-3 vol.\%). Laminated dark gray calcareous shales are characterized by a generally high content of carbonates (calcite predominates over dolomite) and organic matter $\left(2.4-6.3 \mathrm{wt} . \% \mathrm{C}_{\text {org }}\right)$ that form alternating laminae; pyritic framboids are common (1 to 2 vol.\%). Gray streaky non-laminated marlstones occur as thin intercalations within the laminated dark gray calcareous shales. The

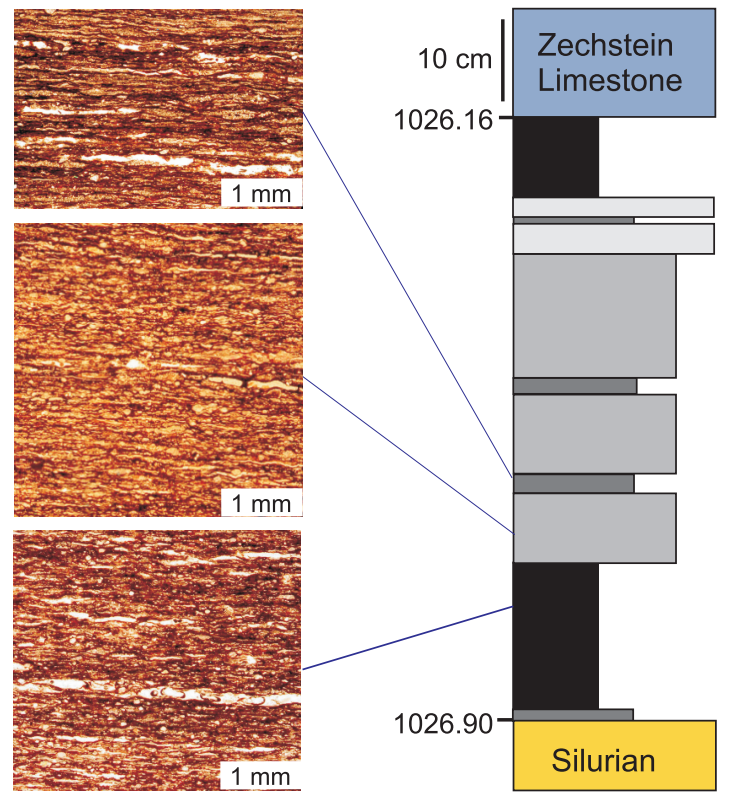

microlitho-

facies a

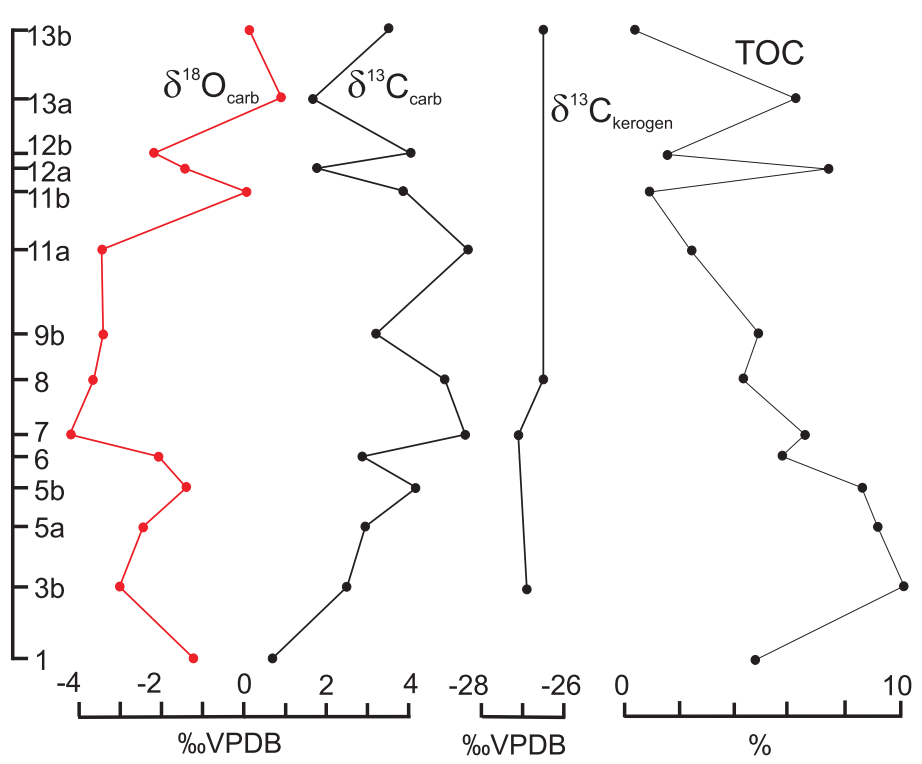

microlithofacies $b$
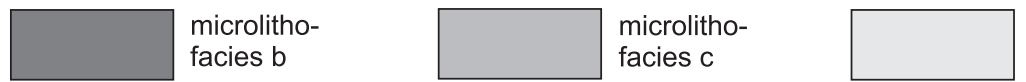

grey streak marlstone

Fig. 3. The Kupferschiefer section of the Zdrada IG 8 borehole showing microlithofacies, sample location, $\delta^{13} \mathrm{C}$ and $\delta^{18} \mathrm{O}$ values of samples and total organic carbon content (TOC)

(a) - organic-rich clayey shale with fine planar discrete laminae composed of clay (brown); abundant dark matrix; microsparitic lamine (white) and possible skeletal remains are concordant with lamination; sparse non-skeletal grains (microsparitic pelletoids); (b) - laminated calcareous muddy shale with wavy and lenticular microsparitic laminae (dark brown); abundant non-skeletal grains (microsparitic pelletoids); (c) - organic-rich muddy shale with fine discrete clay and carbonate laminae and lenticular laminae composed of fine-grained terrigenous material 
marlstones are poor in organic material $\left(<1.5 \mathrm{wt} . \% \mathrm{C}_{\text {org }}\right)$ and contain scattered microcrysts of euhedral pyrite in low abundance (<1 vol.\%) (Pašava et al., 2010).

The Kupferschiefer sequence is usually composed of three or two (full or reduced) cycles that can be correlated throughout the Zechstein basin (Paul, 1982; Oszczepalski and Rydzewski, 1987); each cycle consists of black laminated clayey shales at the base and laminated marlstones at the top. In the Zdrada IG 8 borehole, one full cycle and a rudimentary second cycle (limited to sample 13a, Fig. 3) occur. The cycles are variously interpreted (Pašava et al., 2010, with references therein). It is commonly accepted that the Kupferschiefer and Marl Slate represent a relatively short time interval, probably of less than 20,000 yr (Oelsner, 1959; Hirst and Dunham, 1963; Turner and Magaritz, 1986), and the anoxic events are of much shorter duration: in NE England, sapropel 1 in the Marl Slate is considered to have lasted 5,000 yr (Magaritz and Turner, 1982), sapropel 2 only a few hundred years (Turner and Magaritz, 1986), and the freshwater flooding peaks also represent time intervals of less than 1,000 yr (Turner and Magaritz, 1986). According to Sweeney et al. (1987), the oxic-anoxic boundary "...was static for up to a few thousand years between upward/downward movements".

The Kupferschiefer of the Zdrada IG 8 region was deposited in the shallow part of a mud-dominated stratified shelf sea where deposition from suspension dominated. Initially, sedimentation took place in a low energy anaerobic environment, in deep subtidal conditions below the storm wave base. Calcareous shales and marlstones comprising the middle and upper parts of the Kupferschiefer section were deposited at the transition from the deep to shallow subtidal zone, within the anoxic zone, interspersed with dysaerobic conditions. Anoxic to dysoxic sedimentary environment and anoxic-sulfidic diagenesis of the rocks is additionally shown by various geochemical parameters (see Pašava et al., 2010, for detailed discussion).

The Zechstein Limestone consists of mudstones and wackestones with subordinate oncoid packstones in the lower part of the unit; in the middle and upper parts oncoid packstones (some oncoids are encrusted by foraminifers Peryt and Peryt, 1975) occur which contain intercalations of stromatolite boundstones (Peryt and Peryt, 2012). The Zechstein Limestone is followed by the Lower Werra Anhydrite overlain by the Oldest Halite deposits that are covered by the Upper Anhydrite (Fig. 1). The PZ1 (= Werra) deposits, in turn, are covered by PZ2 (= Stassfurt) deposits (Main Dolomite and Basal Anhydrite) and PZ3 (= Leine) deposits; the latter are restricted in the Zdrada area to the Platy Dolomite (Fig. 1; Peryt et al., 1998).

\section{MATERIAL AND METHODS}

The basal Zechstein strata of the Zdrada IG 8 borehole were recently characterized by Pašava et al. (2010) and Peryt and Peryt (2012), and for this study we have used the previously studied samples, and apply the same sample numeration. The isotopic analyses on the fraction were performed in the Mass Spectrometry Laboratory, Maria Curie-Skłodowska University, Lublin (Poland). Slabbed specimens (with other slabs used to produce standard thin sections) have been sampled selectively and a $1.5 \mathrm{~mm}$ diameter stainless steel drill with tungsten carbide coating was used for material extraction from the surfaces of the specimens. $\mathrm{CO}_{2}$ gas was extracted from the samples by reaction of calcite with $\mathrm{H}_{3} \mathrm{PO}_{4}(\mathrm{McCrea}, 1950)$ at $25^{\circ} \mathrm{C}$ in a vacuum line, following the standard procedure. In addition, a small amount of fresh $\mathrm{P}_{2} \mathrm{O}_{5}$ was used, and $\mathrm{CO}_{2}$ was in contact with it for only a few seconds prior to the usual trapping at $-80^{\circ} \mathrm{C}$ (this was only to make sure no water was released e.g., from liquid inclusions in the samples analysed into the rest of the prep line, which was constantly kept under vacuum and free of moisture; the fractionation related to $\mathrm{P}_{2} \mathrm{O}_{5}$ was tested on reference materials, and no statistically significant shifts were found). The gas was thus purified of $\mathrm{H}_{2} \mathrm{O}$ on a $\mathrm{P}_{2} \mathrm{O}_{5}$ trap and collected on a cold finger. Isotopic compositions were analysed using a modified MI1305 triple-collector mass spectrometer equipped with a gas ion source. Isobaric correction was applied. After subsequent normalization to measured certified reference materials, the isotopic composition was expressed in per mille (\%o) relative to the VPDB international standard. Analytical precision of both $\delta^{13} \mathrm{C}$ and $\delta^{18} \mathrm{O}$ in a sample was $\pm 0.08 \%$.

The sample areas selected for drilling were inspected under a stereomicroscope to identify areas homogeneous in terms of colour, texture and free of cracks and visible inclusions. Considering the diameter of sampling $(1.5 \mathrm{~mm})$, each resulting isotopic measurement reflects both depositional and diagenetic signals.

Three samples (Nos. 3, 7 and 8) from the Kupferschiefer and one sample (No. 13b) from the lowest Zechstein Limestone were analysed as regards their organic geochemistry. In addition, one sample (No. 56) from the top part of the Zechstein Limestone was studied for comparative purposes. Core samples were cleaned from mud contaminations and milled to below $0.2 \mathrm{~mm}$. Screening pyrolysis analyses of rock samples were carried out with Rock-Eval 6. Aliquots of the pulverised samples were extracted with dichloromethane: methanol solution $(93: 7 \mathrm{v} / \mathrm{v})$ in a SOXTEC TM apparatus. After removal of carbonates with hydrochloric acid and extraction of bitumens, rock samples selected for stable carbon isotope analysis of kerogen were combusted in an on-line system. Stable carbon isotope analyses were performed with a Finnigan Delta Plus mass spectrometer. The stable carbon isotope data are shown in $\delta$-notation, relative to the VPDB standard (Coplen, 1995), at an estimated analytical accuracy of $\pm 0.2 \%$.

In addition, chemical analyses for $\mathrm{C}_{\text {org }}$ on the samples used for isotopic study were carried out in an accredited laboratory of the Polish Geological Institute; some results have been reported by Pašava et al. (2010).

\section{RESULTS}

The Kupferschiefer shows a large variation in $\delta^{13} \mathrm{C}$ values, from $+0.7 \%$ at its base to $+5.4 \%$ in its middle part (Fig. 3 and Table 1). The average $\delta^{13} \mathrm{C}$ value is $+3.3 \pm 1.4 \%$. In the topmost part of the Kupferschiefer the $\delta^{13} \mathrm{C}$ values rapidly increase, from $+1.7 \%$ (sample $13 \mathrm{a}$ ) in the Kupferschiefer via $+3.5 \%$ o 
T a b l e 1

Isotopic composition of calcite and organic carbon content in the Kupferschiefer and in two samples of the Zechstein Limestone (Zdrada IG 8 borehole)

\begin{tabular}{|c|c|c|c|c|c|c|c|}
\hline No. & \multicolumn{2}{|c|}{$\begin{array}{l}\text { Stratigraphy and } \\
\text { microlithofacies }\end{array}$} & $\begin{array}{l}\text { Sample } \\
\text { number }\end{array}$ & $\begin{array}{l}\text { Depth } \\
{[\mathrm{m}]}\end{array}$ & $\begin{array}{c}\delta^{13} \mathrm{C} \text { VPDB } \\
{\left[\%{ }^{\circ}\right]}\end{array}$ & $\begin{array}{c}\delta^{18} \mathrm{O} \text { VPDB } \\
{[\% 0]}\end{array}$ & $\begin{array}{l}\mathrm{C}_{\mathrm{org}} \\
{[\%]}\end{array}$ \\
\hline 1 & \multirow{2}{*}{\multicolumn{2}{|c|}{$\begin{array}{l}\text { Zechstein } \\
\text { Limestone }\end{array}$}} & 56 & 1018.20 & $\begin{array}{l}5.08 \\
5.33\end{array}$ & $\begin{array}{r}0.16 \\
-0.34\end{array}$ & n.a. \\
\hline 2 & & & $13 b$ & 1026.12 & 3.51 & 0.21 & 0.30 \\
\hline 3 & \multirow{13}{*}{ 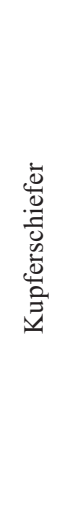 } & $\mathrm{a}$ & $13 \mathrm{a}$ & 1026.21 & 1.67 & 0.79 & 1.52 \\
\hline 4 & & gsm & $12 \mathrm{~b}$ & 1026.27 & 4.02 & -2.09 & 6.31 \\
\hline 5 & & $\mathrm{~b}$ & $12 \mathrm{a}$ & 1026.28 & 1.76 & -1.37 & 7.44 \\
\hline 6 & & gsm & $11 \mathrm{~b}$ & 1026.31 & 3.86 & 0.13 & 0.84 \\
\hline 7 & & $\mathrm{c}$ & $11 \mathrm{a}$ & 1026.36 & 5.43 & -3.39 & 2.40 \\
\hline 8 & & $\mathrm{~b}$ & $9 \mathrm{~b}$ & 1026.48 & 3.2 & -3.37 & 4.94 \\
\hline 9 & & $\mathrm{c}$ & 8 & 1926.57 & 4.88 & -3.54 & 4.39 \\
\hline 10 & & $\mathrm{~b}$ & 7 & 1026.62 & 5.35 & -4.18 & 6.63 \\
\hline 11 & & $\mathrm{c}$ & 6 & 1026.64 & 2.88 & -2.01 & 5.80 \\
\hline 12 & & $\mathrm{c}$ & $5 b$ & 1026.68 & 4.13 & -1.35 & 8.78 \\
\hline 13 & & $\mathrm{a}$ & $5 a$ & 1026.73 & 2.95 & -2.4 & 9.41 \\
\hline 14 & & $\mathrm{a}$ & $3 b$ & 1026.79 & 2.5 & -2.97 & 10.32 \\
\hline 15 & & $\mathrm{~b}$ & 1 & 1026.88 & 0.68 & -1.18 & 4.82 \\
\hline
\end{tabular}

gsm - grey streak marlstone, n.a. - not analysed

(sample 13b) in the lowest part of the Zechstein Limestone to $+5.1 \%$ (sample 15 located $0.5 \mathrm{~m}$ above sample 13a, Fig. 3 ). In the Zechstein Limestone the range of $\delta^{13} \mathrm{C}$ values shows a moderate variation from +3.6 to $+6.4 \%$, the average being +5.1 $\pm 0.6 \%$; $\delta^{13} \mathrm{C}$ data show a long-term trend towards more positive values (Peryt and Peryt, 2012).

The $\delta^{18} \mathrm{O}$ values of the Kupferschiefer show a similar range of variation to the $\delta^{13} \mathrm{C}$ values, from -4.2 to $0.8 \%$ (Fig. 3 and Table 1), the average is $-2.1 \pm 1.5 \%$. The Zechstein Limestone in turn shows a moderate variation only: it ranges from -1.8 to $0.9 \%$, with an average of $-0.5 \pm 0.7 \%$ (Peryt and Peryt, 2012).

The plot of the $\delta^{13} \mathrm{C}$ and $\delta^{18} \mathrm{O}$ values is shown in Figure 3. The very weak correlation $\left(\mathrm{R}^{2}=0.004\right)$ precludes a definite estimation of the functional dependence between the delta values. However, one can note that in spite of unknown functional dependence, the overall trend is a negative correlation.

In Figure 4 microlithofacies a and c clearly show lower $\delta^{13} \mathrm{C}$ values than microlithofacies $b$ and thin intercalations of microlithofacies c occurring in the thicker unit of microlithofacies b, are always characterized by lower $\delta^{13} \mathrm{C}$ values. The lowest $\delta^{13}$ value occurs in the lowest sample (microlithofacies b, Fig. 3). Microlithofacies a show lower $\delta^{13} \mathrm{C}$ values than microlithofacies c. As far as $\delta^{18} \mathrm{O}$ values are concerned, the microlithofacies do not differ (Fig. 4).

Very high TOC (total organic carbon) and bitumen contents were encountered in three samples taken from the Kupferschiefer; they are 4.54 to $14.0 \mathrm{wt} . \%$, and 2990 to 4930 ppm, respectively. Significantly lower values were found in two samples from the Zechstein Limestone: 0.35 and $0.85 \mathrm{wt} . \%$, and 270 and $430 \mathrm{ppm}$, respectively (Table 2). The values of the Rock-Eval hydrogen index (HI), oxygen index (OI), $T_{\max }$ temperature and $\delta^{13} \mathrm{C}$ of kerogen in Kupferschiefer were observed to change as follows: 356 to 424 $\mathrm{mg} \mathrm{HC} / \mathrm{g}$ TOC, 50 to $78 \mathrm{mg} \mathrm{CO} / \mathrm{mg}$ TOC, 409 to $413^{\circ} \mathrm{C}$, and -27.3 to $-26.5 \%$, and in the Zechstein Limestone are as follows: 36 and $37 \mathrm{mg} \mathrm{HC/g}$ TOC, 238 and $266 \mathrm{mg} \mathrm{CO} / \mathrm{mg}$ TOC, 413 and $419^{\circ} \mathrm{C}$, and -26.5 and $-25.8 \%$ (Table 2 ).

The content of organic carbon in the Kupferschiefer ranges from 0.84 to $10.32 \%$ (Fig. 3 and Table 1) and is $5.66 \pm 2.94 \%$ on average.

\section{INTERPRETATION AND DISCUSSION}

The basal Zechstein strata in the Zdrada IG 8 borehole located in the basin centre zone are characterized by a marked general increase in $\delta^{13} \mathrm{C}$ values, from low values in the lower part of the Kupferschiefer to higher values in the Zechstein Limestone (Fig. 1).

The trend observed in the basal Zechstein of the Zdrada IG 8 borehole has also been earlier recognized by several authors (e.g., Marowsky, 1969; Magaritz et al., 1981; Turner and Magaritz, 1986). Magaritz et al. (1981) recorded a change in $\delta^{13} \mathrm{C}$ from "normal marine values" $(0$ to $+2 \%)$ to values higher in $\delta^{13} \mathrm{C}(+3.5$ to $+4.5 \%)$ in Central Germany and NE England and concluded that the carbon isotope trend remains the same despite changes in mineralogy (mainly calcite in Germany and dolomite in NE England). It was assumed that there is no change in $\delta^{13} \mathrm{C}$ values as a result of dolomitisation (Magaritz et al., 1981, p. 249). However, the actual values of $\delta^{13} \mathrm{C}$ appear to be higher in the Marl Slate than in the Kupferschiefer (Magaritz et al., 1981, fig. 4).

In Figures 5 and 6 we show the earlier published $\delta^{13} \mathrm{C}$ and $\delta^{18} \mathrm{O}$ values from central Germany and NE England

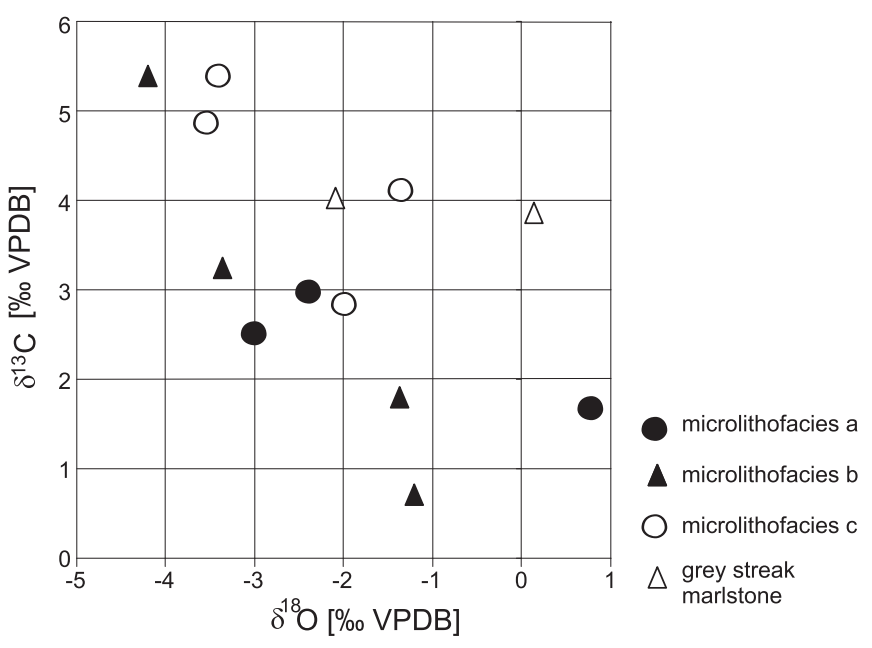

Fig. 4. The plot of the $\delta^{13} \mathrm{C}$ and $\delta^{18} \mathrm{O}$ values of the Kupferschiefer in the Zdrada IG 8 borehole

For microlithofacies description, see explanation to Figure 3 
Results of Rock-Eval analyses, bitumen content and stable carbon isotope composition of kerogen

\begin{tabular}{|c|c|c|c|c|c|c|c|c|c|c|c|}
\hline \multirow[b]{2}{*}{ Stratigraphy } & \multirow[b]{2}{*}{ Lithology } & \multirow[b]{2}{*}{$\begin{array}{l}\text { Sam- } \\
\text { ple } \\
\text { num- } \\
\text { ber }\end{array}$} & \multicolumn{7}{|c|}{ Rock-Eval data } & \multirow[b]{2}{*}{$\begin{array}{l}\text { Bitu- } \\
\text { men ex- } \\
\text { tract } \\
\text { [ppm] }\end{array}$} & \multirow[b]{2}{*}{$\begin{array}{c}\delta^{13} \mathrm{C} \\
\text { (Kerogen) } \\
{[\% 0]}\end{array}$} \\
\hline & & & $\begin{array}{l}\text { TOC } \\
\text { [wt.\%] }\end{array}$ & $\begin{array}{l}T_{\max } \\
{\left[{ }^{\circ} \mathrm{C}\right]}\end{array}$ & $\begin{array}{l}\mathrm{S}_{1} \\
{[\mathrm{mg}} \\
\mathrm{r}\end{array}$ & $\begin{array}{r}\mathrm{S}_{2} \\
\mathrm{HC} / \mathrm{g} \\
\mathrm{ck}]\end{array}$ & $\mathrm{PI}$ & $\begin{array}{c}\mathrm{HI} \\
{[\mathrm{mg} \mathrm{HC} /} \\
\mathrm{g} \text { TOC] }\end{array}$ & $\begin{array}{c}\mathrm{Ol} \\
{\left[\mathrm{mg} \mathrm{CO}_{2} /\right.} \\
\mathrm{g} \text { TOC }]\end{array}$ & & \\
\hline \multirow{2}{*}{$\begin{array}{l}\text { Zechstein } \\
\text { Limestone }\end{array}$} & grey oncoid packstone & 56 & 0.35 & 419 & $\begin{array}{c}0.0 \\
4\end{array}$ & 0.13 & 0.25 & 37 & 266 & 270 & -25.8 \\
\hline & $\begin{array}{c}\text { dark grey peloid-oncoid } \\
\text { packstone }\end{array}$ & $13 b$ & 0.85 & 413 & $\begin{array}{c}0.0 \\
4\end{array}$ & 0.31 & 0.12 & 36 & 238 & 430 & -26.5 \\
\hline \multirow{3}{*}{$\begin{array}{l}\text { Kupferschief } \\
\text { er }\end{array}$} & $\begin{array}{c}\text { dark grey } \\
\text { laminated calcareous } \\
\text { shale (microlithofacies b) }\end{array}$ & 8 & 4.54 & 409 & $\begin{array}{l}0.6 \\
5\end{array}$ & $\begin{array}{c}16.1 \\
8\end{array}$ & 0.04 & 356 & 78 & 2990 & -26.5 \\
\hline & $\begin{array}{l}\text { organic-rich mud shale } \\
\text { with fine clay, calcareous } \\
\text { and siliciclastic laminae } \\
\text { (microlithofacies c) }\end{array}$ & 7 & 6.95 & 413 & 0.9 & $\begin{array}{c}27.3 \\
9\end{array}$ & 0.03 & 394 & 68 & 3600 & -27.3 \\
\hline & $\begin{array}{c}\text { black laminated } \\
\text { clay-shale } \\
\text { (microlithofacies c) }\end{array}$ & 3 & 14.0 & 412 & $\begin{array}{c}1.9 \\
6\end{array}$ & 59.2 & 0.03 & 424 & 50 & 4930 & -27.1 \\
\hline
\end{tabular}

(Marowsky, 1969; Magaritz et al., 1981; Turner and Magaritz, 1986; Sweeney et al., 1987). The original data plotted relative to the thickness of the Kupferschiefer and Marl Slate (Fig. 5A) were then expanded or reduced as required for direct comparison, assuming that those deposits have been formed within the same time interval (see the discussion below; Fig. 5B). This approach allows a partial elimination of regional environmental perturbations.

The increasing trend - from the basal clay unit towards the upper carbonate unit - is maintained in NE England, within the Marl Slate $\delta^{13} \mathrm{C}$ (and $\delta^{18} \mathrm{O}$ ) values first decrease and then increase (Magaritz et al., 1981; Fig. 2). Subsequent detailed study of the Marl Slate (Turner and Magaritz, 1986) showed a general increase in $\delta^{13} \mathrm{C}$ values, with an excursion towards more negative values in the upper part of sapropelic silty dolomicrite (Lithotype 1 of Turner and Magaritz, 1986). In one borehole section in Germany, Buchenau 1 (Magaritz et al., $1981)$, the $\delta^{13} \mathrm{C}$ record shows a very similar pattern to that in the Zdrada IG 8 borehole (Fig. 5B). The P292 and Z23 boreholes (Marowsky, 1969) show first an increase and then a decrease in $\delta^{13} \mathrm{C}$ values in the lowest Zechstein Limestone (P292) or in the upper part of the Kupferschiefer that continues in the lowest Zechstein Limestone (Z23), and in the Ibbenbüren borehole $\delta^{13} \mathrm{C}$ values start to decrease from the base of the Kupferschiefer (Fig. 5). However, it should be taken into account that the published data for Germany have to be treated with caution because detailed lithological data are not available and hence it is not certain that the Kupferschiefer-Zechstein Limestone boundary is identical in all cases. Locally, especially when the $\delta^{18} \mathrm{O}$ values are highly negative, as in the Kupferschiefer sections from Germany reported by Marowsky (1969) and Magaritz et al. (1981), the $\delta^{13} \mathrm{C}$ values are probably not the original ones and hence are not representative. Because during diagenesis the predominant shift of the carbon and oxygen isotopic ratios is toward negative, or less positive, values (Hudson, 1977), the reported data from the Zdrada IG 8 borehole are the closest to the pristine ones as far as the basal Zechstein is concerned (see Fig. 6). However, diagenetic changes in organic-rich sediments in anoxic-sulphidic conditions can impact their $\delta^{13} \mathrm{C}$ values without major change of $\delta^{18} \mathrm{O}$ values. There is quite a good correlation between low $\delta^{13} \mathrm{C}$ values and high organic carbon content suggesting less-decomposed organic matter under anaerobic conditions ( $c f$. Fig. 3).

Variation in $\delta^{18} \mathrm{O}$ values is commonly regarded to reflect the isotopic composition of the water in which the carbonate was formed. Turner and Magaritz (1986) argued that the pattern observed in $\delta^{18} \mathrm{O}$ values of the Marl Slate is related to admixture of two types of water during deposition: seawater and evaporated water enriched in $\delta^{18} \mathrm{O}$ and continental freshwater depleted in $\delta^{18} \mathrm{O}$. The minima in $\delta^{18} \mathrm{O}$ values indicate periods when the influx of freshwater into the basin was at its maximum, and the fact that the peaks embrace several one cm samples and show well-defined trends within individual lithological units indicates that these features are probably primary (cf. Turner and Magaritz, 1986). However, in general the sapropelic units of the Marl Slate have more negative $\delta^{18} \mathrm{O}$ values than the laminites or dolostones (Magaritz et al., 1981; Turner and Magaritz, 1986), and in the Kupferschiefer of the Zdrada IG 8 borehole such a trend is not obvious (Fig. 3): the lowest $\delta^{18} \mathrm{O}$ value is from the lower intercalation of microlithofacies b within microlithofacies c, and microfacies a shows a low $\delta^{18} \mathrm{O}$ value in one case and the highest value in an other case (Fig. 3).

The Kupferschiefer shales contain much more dispersed organic matter than the Zechstein Limestone carbonates (Table 2). The values of Rock-Eval hydrogen index (HI), oxygen index (OI), $T_{\max }$ temperature and residual hydrocarbon potential (S2) (Table 2; Figs. 7 and 8) indicate the dominance of algal type II kerogen in the Kupferschiefer shales, and terrestrial type III kerogen in the Zechstein Limestone carbonates. The Kupferschiefer profiles of boreholes in south-west Poland (Kotarba et al., 2006) also show high contents of the same type of organic matter (up to 10.8 wt.\% TOC), but the Zechstein Limestone carbonates contain insignificant quantities of organic matter (usually less than $0.1 \mathrm{wt} . \%$ TOC). 


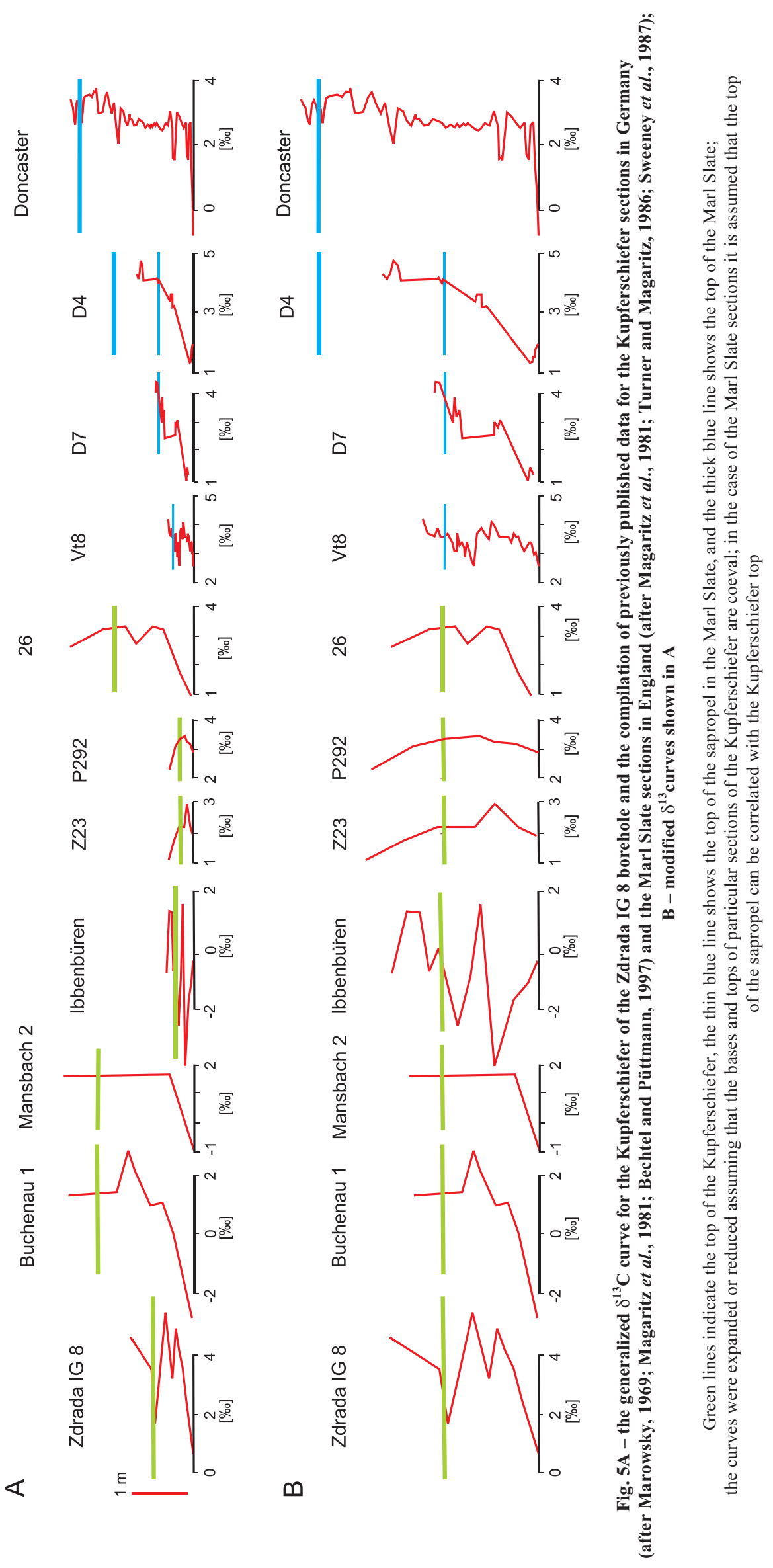




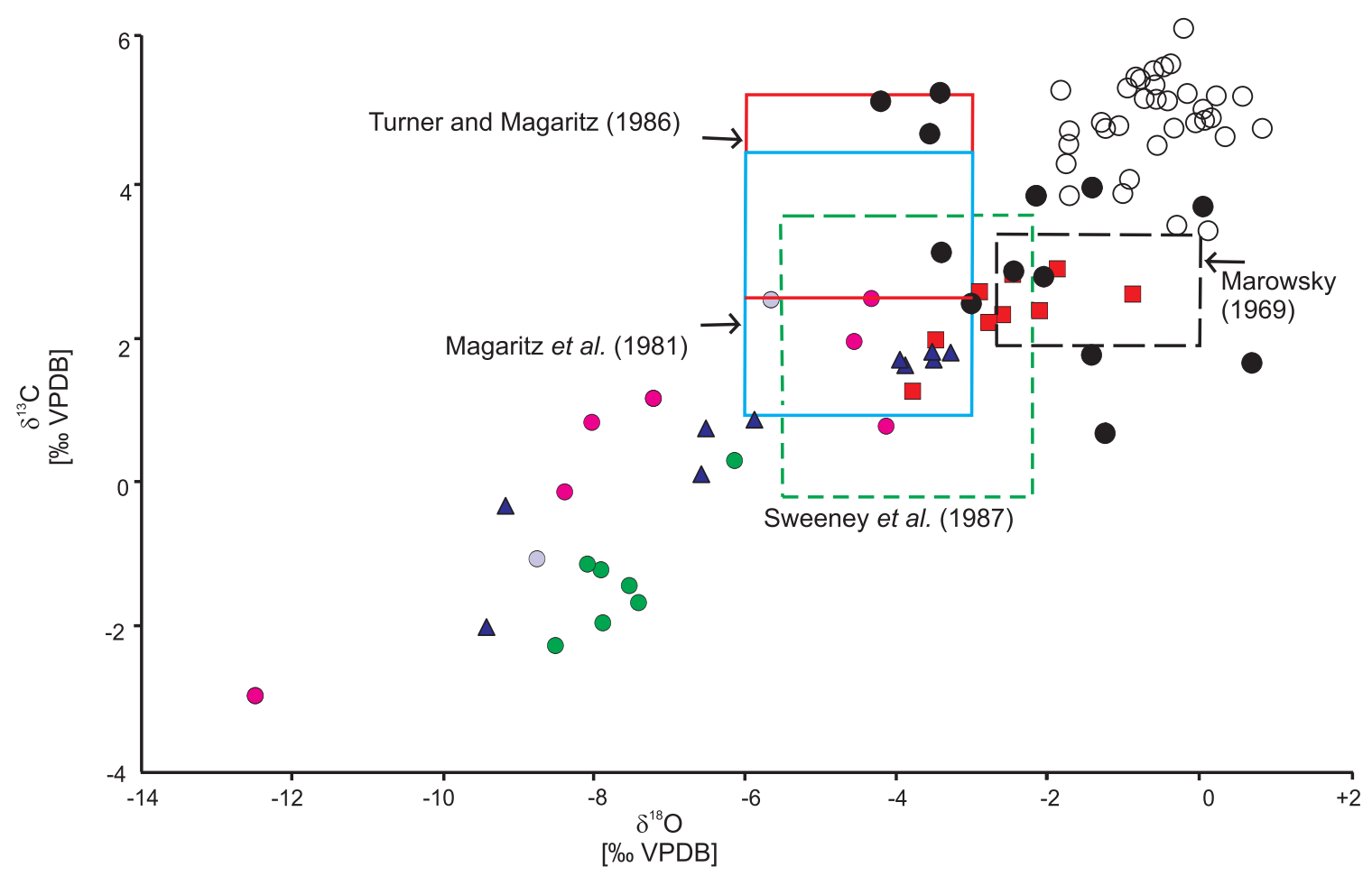

Kupferschiefer, Zdrada IG 8 borehole
Kupferschiefer, Mansbach 2 (Magaritz et al., 1981)
Kupferschiefer, Buchenau 1 (Magaritz et al., 1981)
Kupferschiefer, Rote Fäule facies, SW Poland (Bechtel et al., 2002)
Kupferschiefer, Cu facies, SW Poland (Bechtel et al., 2002)
Kupferschiefer, Pb/Zn facies, SW Poland (Bechtel et al., 2002)
Zechstein Limestone, Zdrada IG 8 borehole (Peryt and Peryt, 2012)

Fig. 6. The plot of the $\delta^{13} \mathrm{C}$ and $\delta^{18} \mathrm{O}$ values of the Kupferschiefer in Poland and Germany and the Marl Slate in England

Boxes show the range of the values for the Marl Slate (Magaritz et al., 1981; Turner and Magaritz, 1986; Sweeney et al., 1987) and for two boreholes (P292 and Z23) of the Kupferschiefer in West Germany (Marowsky, 1969)

Rock-Eval $T_{\max }$ temperature values below $435^{\circ} \mathrm{C}$ (Espitalié and Bordeneve, 1993) show that organic matter within these lithostratigraphic divisions is immature (Fig. 8). The Kupferschiefer organic matter was deposited in a reducing environment and the Zechstein Limestone organic matter was subject to oxidizing processes (Fig. 8).

The $\delta^{13} \mathrm{C}$ values of kerogen in Kupferschiefer and Zechstein Limestone strata vary from -27.3 to $-25.8 \%$ o (Table 2). The comparison of changes in $\delta^{13} \mathrm{C}_{\text {carb }}$ and $\delta^{13} \mathrm{C}_{\text {kerogen }}$ values in the Kupferschiefer and the Zechstein Limestone of the Zdrada IG 8 borehole is shown in Figure 3. These $\delta^{13} \mathrm{C}$ variations in carbonate and organic matter of the profile analysed match the general trend in the Permian (see fig. 41 in Galimov, 2006; Hermann et al., 2010). The change in the intensity of bioproduction and thus the shift in $\delta^{13} \mathrm{C}$ values of both organic and carbonate carbon was the most important event in the context of global tectonics and climate change (Galimov, 2006). A model of the global isotope balance that interprets the isotope variability in $\delta^{13} \mathrm{C}_{\text {carb }}$ and $\delta^{13} \mathrm{C}_{\text {kerogen }}$ values has been suggested (Galimov, 1999, 2006). No positive correlation has been observed between stable carbon isotopes in carbonates $\left(\delta^{13} \mathrm{C}_{\text {carb }}\right)$ and organic matter $\left(\delta^{13} C_{\text {kerogen }}\right)$ of black shales of the
Kupferschiefer (Fig. 3) as is characteristic of Oceanic Anoxic Events (e.g., Jenkyns, 2010; Jarvis et al., 2011). Typically, if both the $\delta^{13} \mathrm{C}$ of the inorganic and organic portions co-vary in a sedimentary sequence, it is assumed that the variations in the $\delta^{13} C_{\text {inorganic }}$ values indicate a real change in the $\delta^{13} C_{\text {inorganic }}$ of the environment (e.g., Underwood et al., 1997; Jarvis et al., 2006). However, Oehlert et al. (2012) indicated that within a relatively short distance from the platform margin there are completely different patterns in the association of $\delta^{13} \mathrm{C}_{\text {organic }}$ and $\delta^{13} \mathrm{C}_{\text {inorganic }}$ values because bulk records are sourced from a variety of producers in the shallow marine and pelagic environment. The lack of correlation between $\delta^{13} \mathrm{C}_{\text {carb }}$ and $\delta^{13} \mathrm{C}_{\text {kerogen }}$ in black shales of the Kupferschiefer (Fig. 3) can be related both to diagenetic changes and to primary variation in epeiric seas ( $c f$. Oehlert et al., 2012).

\section{IMPLICATIONS}

The Kupferschiefer deposition lasted at most some tens of thousands of years, and the laminated clayey shales were de- 


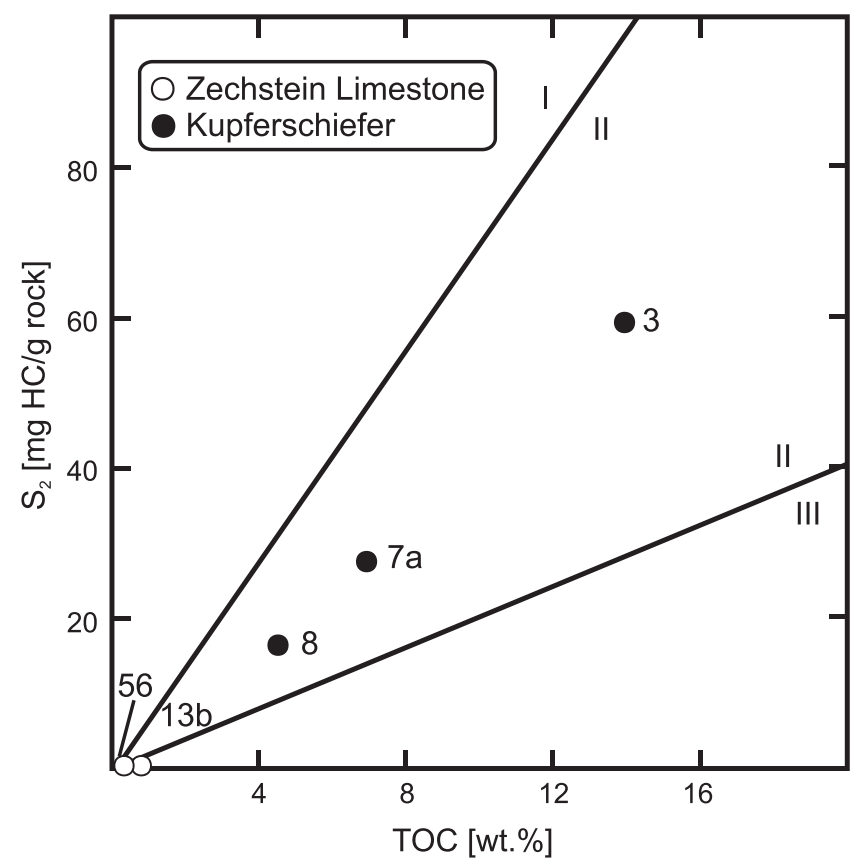

Fig. 7. Residual petroleum potential $S_{2}$ versus total organic carbon (TOC) content revealing the kerogen type in Kupferschiefer and Zechstein Limestone strata

Genetic boundaries after Langford and Blanc-Valleron (1990)

posited during a longer time span than the laminated marlstones (see discussion in Pašava et al., 2010). In contrast, the sedimentation of the Zechstein Limestone was estimated as lasting 1 Ma by Peryt (1984). Altogether, the Zechstein corresponds to the very last 5-7 My of the Permian (Menning, 1995), although Menning et al. (2005) proposed a duration of the complete Zechstein succession, based on a cyclostratigraphic interpretation, of about 2.8 Ma. Denison and Peryt
(2009), based on ${ }^{87} \mathrm{Sr} /{ }^{86} \mathrm{Sr}$ ratios of anhydrites, suggested that the deposition of the sequence examined (Upper Anhydrite-Basal Anhydrite) lasted approximately 2 Ma.

The sharp change in the carbon isotopic composition, from the low $\delta^{13} \mathrm{C}$ values at the beginning of the Kupferschiefer (Figs. 1 and 3 ) to the high values characteristic of Zechstein carbonates (Fig. 1), lasted only a few thousand years, if the assumptions regarding the length of deposition of particular lithologies of the Kupferschiefer and the Marl Slate are correct. Magaritz et al. (1983) reported high $\delta^{13} \mathrm{C}$ values from the Castile Formation of the Delaware Basin (USA) and suggested a dramatic rise from -2.8 to $+5.7 \%$ in only 4400 years. They correlated the Delaware record with similar records from the Zechstein Basin and postulated that the event was world-wide; this, however, poses obvious difficulties for the carbon cycle (Magaritz et al., 1983). Holser and Magaritz (1987, p. 159, 160) consider that the onset of this final carbon high was coeval but they admit that although similar, the profiles are not identical in detail. In the Delaware Basin, the transition occurs just before the change in facies from clastic deposits (claystones and siltstones) of the Bell Canyon Formation to evaporites of the Castile Formation (Magaritz et al., 1983). However, there are serious doubts whether the phases analysed by Magaritz et al. (1983) represent primary undisturbed material, i.e., material which reflects possible original seawater conditions. There are good reasons to conclude that, as in the case of the sandstones and siltstones, most of the material analysed probably consisted of intermediate to late-stage diagenetic carbonate cements (Arthur, 1984; Scholle, 1995). As concluded by Scholle (1995, p. 144), "When data from organic-rich shales, sandstone cements, marine limestones, and concretionary carbonates are combined in a secular variation curve, it is not surprising that isotopic shifts coincide with formational boundaries". Recent study of the top part of the Reef Trail Member of the Bell Canyon Formation indicated a large negative isotope shift of $4.5-5 \%$ in

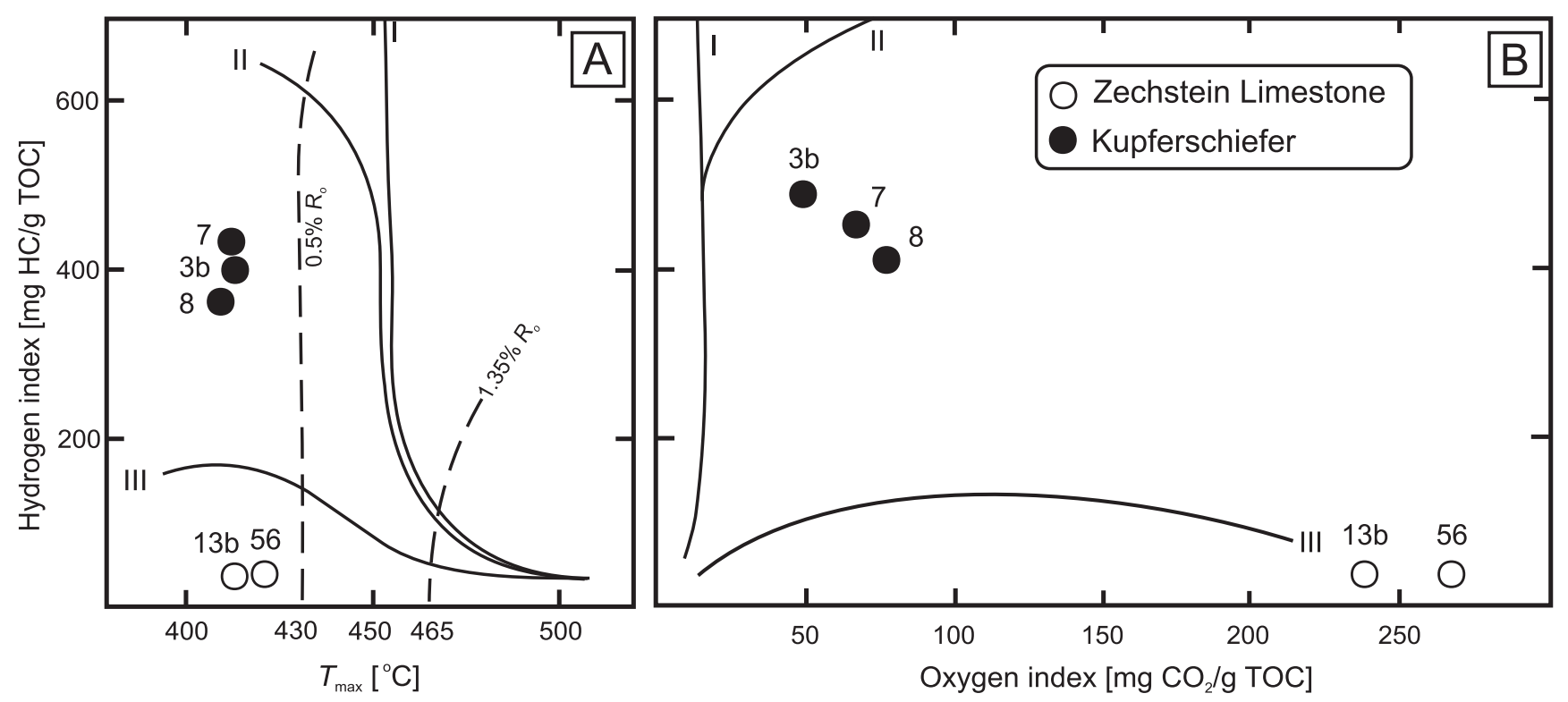

Fig. 8. Rock-Eval hydrogen index versus (A) $T_{\max }$ temperature and (B) oxygen index 
$\delta^{13} \mathrm{C}$ from whole-rock inorganic carbon which appears to correlate with the start of a globally recognized negative excursion associated with the mid-Guadalupian mass extinction (Noble et al., 2009). Both fine and coarse grained lithologies show comparable shifts, and the associated changes in radiolarian assemblages indicate that the shift records ecological/environmental variation, and is not a diagenetic signal (Noble et al., 2009). Noble et al. (2009) found that this shift continues into the Castile Formation.

The large-scale relative carbon isotopic shifts recorded in continual marine sections, such as the Middle Permian Delaware Basin, can reflect real shifts in oceanic chemistry through time, but it is doubtful that the change recorded in the basal Zechstein deposits is identical with that in the Delaware Basin. The Zechstein basin came into existence after radical environmental change when the Southern Permian Basin, which was an intracontinental depression located well below the contemporaneous sea level during most of the Permian (Gast et al., 2010, with references therein), was flooded catastrophically (Smith, 1979) and became a marginal sea. Therefore, although the isotopic effects of changes which occurred in the Delaware and the Zechstein landlocked basins are similar, they resulted from different mechanisms

Marginal seas, such as the Delaware Basin (and the Zechstein basin), have high $\delta^{13} \mathrm{C}$-signals relative to their Tethyan counterparts (Korte et al., 2005); they also show higher $\delta^{18} \mathrm{O}$ values for brachiopods, perhaps reflecting a slight $\delta^{18} \mathrm{O}$ enrichment of seawater due to high evaporation rates in the basin (Korte et al., 2005). The carbon isotope curve for the Capitanian and Wuchiapingian carbonates developed on an ancient seamount in mid-Panthalassa (Kamura area, Kyushu, Japan) shows that the high positive $\delta^{13} \mathrm{C}$ values $(+5$ to $+6 \%$ ) (Kamura event) continued until the late Capitanian; after three negative shifts the $\delta^{13} \mathrm{C}$ value felt to $+2 \%$ (Isozaki et al., 2007). The very similar $\delta^{13} \mathrm{C}$ composite curve derived from the study of the Capitanian and lower Wuchiapingian platform carbonates of South China can be correlated with the Panthalassan seamount record and with that of the Zdrada IG 8 borehole (Fig. 9A). The $\delta^{13} \mathrm{C}$ record from sections in South China, calibrated against a high-resolution conodont biostratigraphy, revealed a major intra-Capitanian negative excursion (of $>5 \%$; Fig. 9A); the Capitanian mass extinction occurs during the early stage of this excursion (Bond et al., 2010). Subsequently, the $\delta^{13} \mathrm{C}$ values increase rapidly to $3.5 \%$ (Bond et al., 2010, fig. 11 ) and then the values increase gradually to $5.5 \%$ in the topmost Capitanian (Wang et al., 2004; Fig. 9A). In the lowest Wuchiapingian a moderate depletion of $c a$. $1.5 \%$ occurs (Wang et al., 2004; Bond et al., 2010; Isozaki et al., 2011) that is followed by a general increase in $\delta^{13} \mathrm{C}$ values (Fig. 9A), with some positive and negative 1\% excursions (Korte et al., 2004; Bond et al., 2010), to the previous high values of $c a$. 5\%. However, the moderate excursion in the lowest Wuchiapingian does not occur in some areas, e.g. in Oman (Koehrer et al., 2010).

At $258 \mathrm{Ma}$ the $\delta^{13} \mathrm{C}$ values decreased with an amplitude of 0.9-1.5\%o to $+3 \%$ (Isotope Event 0 - Richoz et al., 2010) and then they increased and remained steady around a relatively high value of $4-5 \%$ for several Ma until a consistent, gradual and progressive decline in $\delta^{13} \mathrm{C}$ through late Changhsingian strata occurred (Cao et al., 2010; Gaetani et al., 2009; Korte et al., 2010; Fig. 9A); this decline began in the early Changhsingian at ca. $255 \mathrm{Ma}$ (Isotope Event 1 - Richoz et al., 2010).

Considering the high positive $\delta^{13} \mathrm{C}$ values of the Zechstein carbonates starting from the Zechstein Limestone (Fig. 1), and that the Zechstein show high $\delta^{13} \mathrm{C}$-signals relative to their Tethyan counterparts (Korte et al., 2005), they fit well the interval of relatively high $\delta^{13} \mathrm{C}$ values related to the upper Wuchiapingian and the lower Changhsingian (Fig. 9A). In the lowest Zechstein, there is a clear increase in the $\delta^{13} \mathrm{C}$ values, and the highest positive values (exceeding 8\% - Peryt et al., $2010 b$ ) have been recorded in the Main Dolomite. In the Platy Dolomite the $\delta^{13} \mathrm{C}$ values drop slightly ( $c f$. Fig. 1). When compared to the generalized isotopic curve for the late Permian proposed by Richoz et al. (2010), the increase in the $\delta^{13} \mathrm{C}$ values observed after Isotope Event 0 (some $258 \mathrm{Ma}$ ) fits well the increase (although more significant) from the Kupferschiefer till the Main Dolomite. In turn, the subsequent slight fall that accelerated after Isotope Event 1 (Richoz et al., 2010) fits the fall (although more significant) in the Platy Dolomite. If - as we assume - the Platy Dolomite corresponds to the time around Isotope Event 1, then the time interval encompassing the Upper Werra-Main Anhydrite deposition would be around $2 \mathrm{Ma}(c f$. Denison and Peryt, 2009), and the interval of Zechstein deposition would amount ca. 5.5 Ma. This value fits the range of 5-7 Ma for the Zechstein concluded by Menning (1995).

The $\delta^{13} \mathrm{C}$ curve from the Kupferschiefer and the Zechstein Limestone of the Zdrada IG 8 borehole calibrated for $1 \mathrm{Ma}$ (Fig. 9B) and 0.5 Ma (Fig. 9C) shows a striking similarity to the composite $\delta^{13} \mathrm{C}$ record from sections in South China (Bond et al., 2010) that represent the upper Guadalupian (Fig. 9A) and specifically to the $\delta^{13} \mathrm{C}$ curve around the sequence boundary (SB in Fig. 9A) following the mid-Guadalupian extinction. However, the early Wuchiapingian age of conodonts recorded in basal Zechstein deposits excludes such a possibility. Permian conodonts show very distinct provincialism, and conodonts from the Zechstein basin and Eastern Greenland belong to the Northern Cool Water Province (Mei and Henderson, 2001). The Mesogondolella rosenkrantzi and Merrillina divergens fauna in Eastern Greenland (Bender and Stoppel, 1965; Sweet, 1976; Rasmussen et al., 1990) is interpreted to be Lopingian, as it is associated with Cyclolobus which is Wuchiapingian-Changhsingian in age (Zhou et al., 1996); in the Salt Range Cyclolobus has been found to occur with late Wuchiapingian to early Changhsingian conodonts (Wardlaw and Mei, 1999). The base of the Eastern Greenland equivalents of the Zechstein is put into the middle part of Wuchiapingian (e.g., Sørensen et al., 2007). Conodonts from the Zechstein Basin are dominated by Merrillina divergens (Szaniawski, 1969; Swift and Aldridge, 1986; Swift, 1995); Mesogondolella is not common in the Zechstein, and is referred to as M. britannica by Kozur (1998). Although indirectly, the Zechstein conodont fauna suggests a Wuchiapingian, and not Guadalupian age ( $c f$. Legler and Schneider, 2008).

Recently it was suggested that the interval of Zechstein deposition is longer, and the Zechstein base was shifted down to 260.4 Ma (Wagner, 2009; Słowakiewicz et al., 2009), being equivalent to the Guadalupian/Lopingian boundary, but such a 


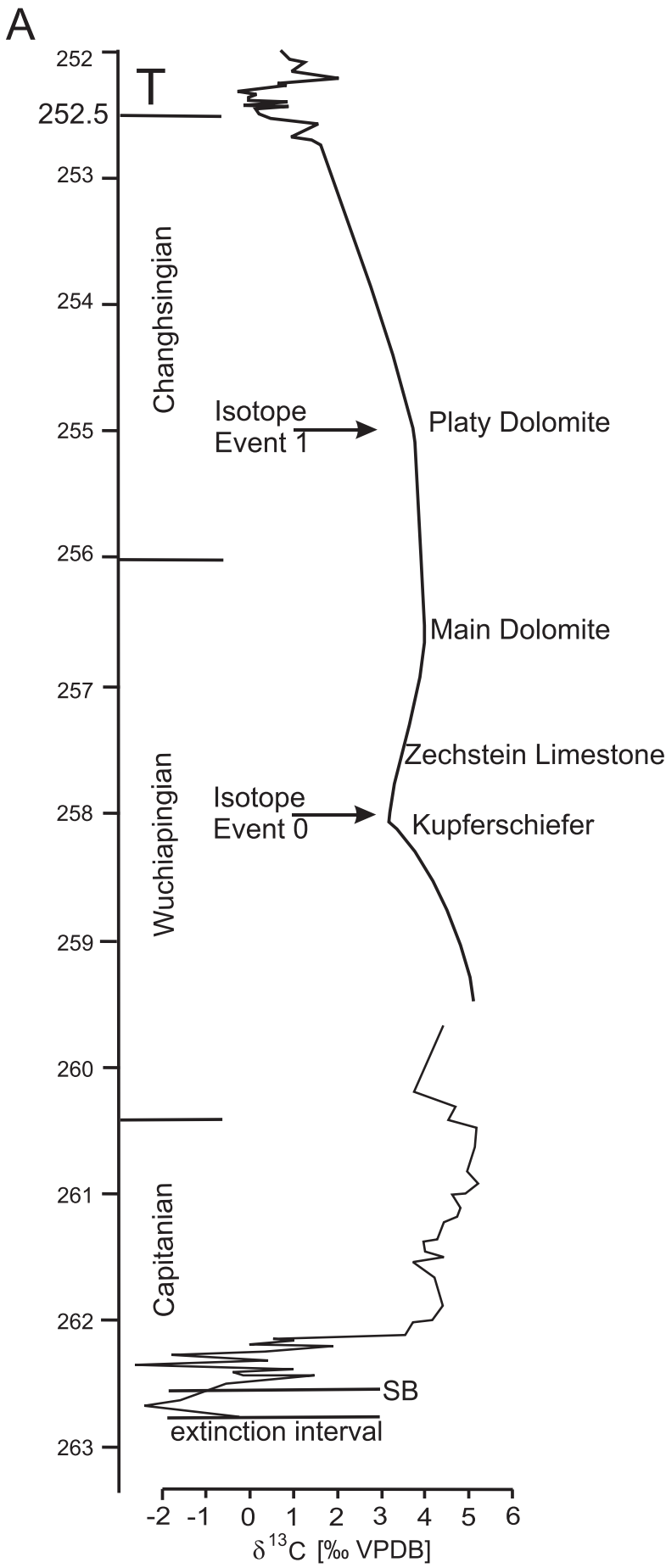

B
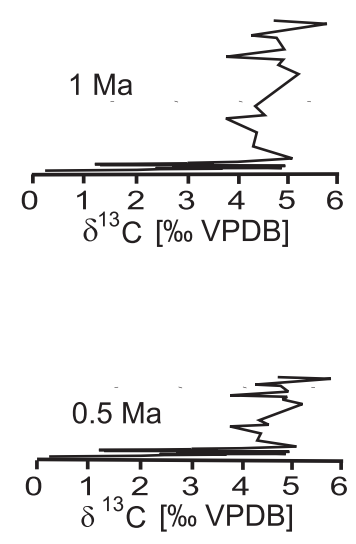

speculative concept has no support in the data and it ignores the fact that rapid changes in $\delta^{13} \mathrm{C}$ values in the basal Zechstein are not compatible with the gradual changes of $\delta^{13} \mathrm{C}$ values recorded at the Guadalupian/Lopingian boundary (Isozaki et al., 2007; Bond et al., 2010).

As commonly observed in the deep shelf area of the Kupferschiefer, lamination in the uppermost part of the Kupferschiefer is locally disrupted by small cryptoburrows, which have been made by a soft-bodied infauna (with a lack of skeletal remains), with the highest intensity at the top of the Kupferschiefer (Oszczepalski and Rydzewski, 1987, fig. 5). As a result, the boundary between the Kupferschiefer and the Zechstein Limestone is gradual and is marked by a upwards transition from unfossiliferous, partially cryptobioturbated shales into homogeneous (totally bioturbated) fossiliferous carbonates. It is likely that the termination of the deposition of the Kupferschiefer laminites was caused by:

- a further shallowing of the sedimentary basin (Gerlach and Knitzschke, 1978);

- better circulation of the sea water as a result of eustatic sea level changes (Smith, 1979; Peryt, 1984);

- lowering of the redoxcline below the storm wave base due to a decrease in the surface water organic productivity (Paul, 1982; Oszczepalski and Rydzewski, 1987; Sweeney et al., 1987).

It seems plausible that pulsed changes in sedimentary conditions caused by vertical shifts in the redoxcline position were of primary importance. The rise of the redoxcline resulted in progradation of anoxic sedimentation, whereas its lowering caused the area of anoxic sediments to be restricted. Such fluctuations produced multicycle sequences of the Kupferschiefer, correlated throughout the basin (Rentzsch, 1965; Gerlach and Knitzschke, 1978). Despite this cause, an marked expansion of the fauna and an associated gradual increase in the homogenization of laminated sediments terminated the deposition of the Kupferschiefer. In any case, in the deeper shelf area - in which the Kupferschiefer of the Zdrada IG 8 borehole was deposited there is absolutely no sign of the large hiatus (a few millions of years) needed to combine the Wuchiapingian age of the Zechstein Limestone conodonts and the mid-Capitanian age concluded from the similarity of isotopic curves characteristic of the middle Guadalupian and the basal Zechstein (Fig. 9). Therefore, we reject the correlation of the Kupferschiefer $\delta^{13} \mathrm{C}$ curve and a negative excursion corresponding to a major sequence boundary in the upper Guadalupian although it seems plausible from other points of view.

Fig. 9A - General isotopic curve for the late Permian (after Richoz et al., 2010) showing the presumed position of the Kupferschiefer and Zechstein carbonate units, and the composite $\delta^{13} \mathrm{C}$ record for the late Guadalupian and the earliest Wuchiapingian in South China (after Bond et al., 2010), showing the top of the extinction interval and the sequence boundary (SB); B, C $-\delta^{13} \mathrm{C}$ curve for the Kupferschiefer and Zechstein Limestone in the Zdrada IG 8 borehole assuming the duration of both units as $1 \mathrm{Ma}(\mathrm{B})$ and $0.5 \mathrm{Ma}(\mathrm{C})$ 


\section{CONCLUSIONS}

1. The Kupferschiefer of the Zdrada IG 8 borehole located in Northern Poland shows a large variation in $\delta^{13} \mathrm{C}$ values (from +0.7 to $+5.4 \%$; average $+3.3 \pm 1.4 \%$ ) and $\delta^{18} \mathrm{O}$ values (from -4.2 to $0.8 \%$; average $-2.1 \pm 1.5 \%$ ). The $\delta^{13} \mathrm{C}$ values change from $+0.7 \%$ at the Kupferschiefer base to $+5.4 \%$ in its middle part, then decrease to $+1.7 \%$ at the Kupferschiefer top and than rapidly increase to $+3.5 \%$ (in the lowest part of the Zechstein Limestone) and then to $+5.1 \%$ ( $(0.5 \mathrm{~m}$ above). This increasing trend continued subsequently during the Zechstein Limestone deposition.

2. The trend in carbon isotopic composition towards higher $\delta^{13} \mathrm{C}$ values observed in the basal Zechstein of the Zdrada IG 8 borehole was earlier recognized by several authors in the Kupferschiefer of Germany and the Marl Slate of England. The $\delta^{18} \mathrm{O}$ values from the Zdrada IG 8 borehole indicate that they are the closest to pristine ones as far as the basal Zechstein is concerned.

3. Although the $\delta^{13} \mathrm{C}$ curve shows that the best place for the Zechstein base may lie near the sequence boundary in the upper Guadalupian of South China that postdated the mid-Guadalupian extinction, the early Wuchiapingian conodonts reported from the basal Zechstein deposits elsewhere in the Puck Bay area (Szaniawski, 1969) exclude such an interpretation.

4. When compared to the generalized isotopic curve for the Late Permian proposed by Richoz et al. (2010), the increase in the $\delta^{13} \mathrm{C}$ values recorded in the interval from the Kupferschiefer till the Main Dolomite fits well that observed after Isotope Event 0 (some $258 \mathrm{Ma}$ ), although the increase in the Zdrada IG 8 is clearly more significant than is shown in the global $\delta^{13} \mathrm{C}$ curve. In turn, the subsequent slight fall that accelerated after Isotope Event 1 (Richoz et al., 2010) fits the fall although a more significant one in the Platy Dolomite.

5. The Kupferschiefer shales contain high quantities of immature, algal type II kerogen (TOC content up to $14.0 \mathrm{wt} . \%$, and the bitumen content ranges from 2990 to $4930 \mathrm{ppm}$ ), whereas the Zechstein Limestone carbonates contain less immature, terrestrial type III kerogen (TOC content 0.35 and 0.85 wt.\% and bitumen contents of 270 and $430 \mathrm{ppm}$ ). The Kupferschiefer organic matter was deposited in a reducing environment and the Zechstein Limestone organic matter underwent oxidation. The ${ }^{13} \mathrm{C}$ variations in carbonate and organic matter of the Kupferschiefer and Zechstein Limestone profile match the general trend in Late Permian time.

Acknowledgements. The study was supported by the Ministry of Science and Higher Education (statutory research of the PGI-NRI, project No. 61.5101.1101.00.0; and statutory research of the Faculty of Geology, Geophysics and Environmental Protection at the AGH University of Science and Technology in Kraków, project No. 11.11.140.560 - analysts: H. Zych and T. Kowalski). We thank A. Becker, A. Demény, M. Menning, and an anonymous reviewer for their helpful remarks on and criticism of the first draft of this paper.

\section{REFERENCES}

ARTHUR M. A. (1984) - Carbon isotope anomalies? Nature, 310: 450-451.

BECHTEL A. and PÜTTMANN W. (1997) - Palaeoceanography of the early Zechstein Sea during Kupferschiefer deposition in the Lower Rhine Basin (Germany): a reappraisal from stable isotope and organic geochemical investigations. Palaeogeogr. Palaeoclimatol. Palaeoecol., 136: 331-358.

BECHTEL A., GRATZER R., PÜTTMANN W. and OSZCZEPALSKI S. (2002) - Geochemical characteristics across the oxic/anoxic interface (Rote Fäule front) within the Kupferschiefer of the Lubin-Sieroszowice mining district (SW Poland). Chem. Geol., 185: 9-31.

BENDER H. and STOPPEL D. (1965) - Perm-Conodonten. Geol. Jb., 82: 331-364.

BOND D. P. G., WIGNALL P. B., WANG W., IZON G., JIANG H.-S., LAI X.-L., SUN Y.-D., NEWTON R. J., SHAO L.-Y., VÉDRINE S. and COPE H. (2010) - The mid-Capitanian (Middle Permian) mass extinction and carbon isotope record of south China. Palaeogeogr. Palaeoclimatol. Palaeoecol., 292: 282-294.

BOTZ R. and MÜLLER G. (1987) - Geochemical investigations of Upper Permian carbonates (Zechstein) and associated organic matter in the NW-German basin. Chem. Erde, 46: 131-143.

CAO C. Q., YANG Y. C., SHEN S. Z., WANG W., ZHENG Q. F. and SUMMONS R. E. (2010) - Pattern of $\delta^{13} \mathrm{C}_{\text {carb }}$ and implications for geological events during the Permian-Triassic transition in South China. Geol. J., 45: 186-194.

CLARK D. N. (1980) - The diagenesis of Zechstein carbonate sediments. Contr. Sediment., 9: 167-203.
COPLEN T. B. (1995) - Reporting of stable carbon, hydrogen, and oxygen isotopic abundances. In: Reference and Intercomparison Materials for Stable Isotopes of Light Elements. Proceedings of a consultants meeting held in Vienna, 1-3 December 1993. International Atomic Energy Agency, Vienna: 31-34.

DENISON R. E. and PERYT T. M. (2009) - Strontium isotopes in the Zechstein (Upper Permian) anhydrites of Poland: evidence of varied meteoric contributions to marine brines. Geol. Quart., 53 (2): $159-166$.

ESPITALIÉ J. and BORDENEVE M. L. (1993) - Rock Eval pyrolysis. In: Applied Petroleum Geochemistry (ed. M. L. Bordeneve): 237-261. Technip, Paris.

ESPITALIÉ J., DEROO G. and MARQUIS F. (1985) - La pyrolyse Rock Eval et ses applications. Revue Inst. Fran. Petr., 40: 755-784.

GAETANI M., ANGIOLINI L., UENO K., NICORA A., STEPHENSON M. H., SCIUNNACH D., RETTORI R., PRICE G. D. and SABOURI J. (2009) - Pennsylvanian-Early Triassic stratigraphy in the Alborz Mountains (Iran). Geol. Soc., London, Spec. Publ., 312: 79-128.

GALIMOV E. M. (1999) - The causes of the global variations of carbon isotope composition in the biosphere. Geochem. Intern., 37: 699-713.

GALIMOV E. M. (2006) - Isotope organic geochemistry. Org. Geochem., 37: $1200-1262$

GAST R. E., DUSAR M., BREITKREUZ C., GAUPP R., SCHNEIDER J. W., STEMMERIK L., GELUK M. C., GEISLER M., KIERSNOWSKI H., GLENNIE K. W., KABEL S. and JONES N. S. (2010) Rotliegend. In: Petroleum Geological Atlas of the Southern Permian Basin Area (eds. J. C. Doornenbal and A. G. Stevenson): 101-121. EAGE Publ. b.v. (Houten) 
GERLACH R. and KNITZSCHKE G. (1978) - Sedimentationzyklen au der Zechstein basin (Z1) im SE-Harzvorland und ihre Beziehungen zu einigen bergtechnischen Problemen. Z. angew. Geol., 24 (5): 214-221.

HERMANN E., HOCHULI P. A., BUCHER H., VIGRAN J. O., WEISSERT H. and BERNASCONI S. M. (2010) - A close-up view of the Permian-Triassic boundary based on expanded organic carbon isotope records from Norway (Tørndelag and Finnmark Platform). Glob. Planet. Change, 74: 156-167.

HIRST D. M. and DUNHAM K. C. (1963) - Chemistry and petrography of the Marl Slate of S. E. Durham, England. Econ. Geol., 58: 912-940.

HOLLINGWORTH N. and PETTIGREW T. (1988) - Zechstein reef fossils and their palaeoecology. Palaeontol. Ass., University Printing House, Oxford.

HOLSER W. T. and MAGARITZ M. (1987) - Events near the Permian-Triassic boundary. Modern Geol., 11: 155-180.

HUDSON J. D. (1977) - Stable isotopes and limestone lithification. J. Geol. Soc. London, 133: 637-660.

HUTTEL P. (1989) - Das Stassfurt-Karbonat (Ca2) in Südoldenburg Fazies und Diagenese eines Sedimentes am Nordhang der Hunte-Schwelle. Gött. Arb. Geol. Paläont., 39.

ISOZAKI Y., KAWAHATA H. and OTA A. (2007) - A unique carbon isotope record across the Guadalupian-Lopingian (Middle-Upper Permian) boundary in mid-oceanic paleo-atoll carbonates: the high productivity "Kamura event" and its collapse in Panthalassa. Global Planet. Change, 55: 21-38.

ISOZAKI Y., ALJINOVIĆ D. and KAWAHATA H. (2011) - The Guadalupian (Permian) Kamura event in European Tethys. Palaeogeogr. Palaeoclimatol. Palaeoecol., 308: 12-21.

JARVIS I., GALE A. S., JENKYNS H. C. and PEARCE M. A. (2006) Secular variation in Late Cretaceous carbon isotopes: a new $\delta^{13} \mathrm{C}$ carbonate reference curve for the Cenomanian-Campanian (99.6-70.6 Ma). Geol. Mag., 143 561-608.

JARVIS I., LIGNUM J. S., GRÖCKE D. R., JENKYNS H. C. and PEARCE M. A. (2011) - Black shale deposition, atmospheric $\mathrm{CO}_{2}$ drawdown, and cooling during the Cenomanian-Turonian Oceanic Anoxic Event. Paleoceanography, 26: 1-17.

JENKYNS H. C. (2010) - Geochemistry of oceanic anoxic events. Geochem. Geophys. Geosyst., 11: 1-22.

KOEHRER B., ZELLER M., AIGNER T., POEPPELREITER M., MILROY P., FORKE H. and AL-KINDI S. (2010) - Facies and stratigraphic framework of a Khuff outcrop equivalent: Saiq and Mahil formations, Al Jabal al-Akhdar, Sultanate of Oman. GeoArabia, 15: 91-156.

KORTE C. and KOZUR H. W. (2010) - Carbon-isotope stratigraphy across the Permian-Triassic boundary: a review. J. Asian Earth Sc., 39: $215-235$.

KORTE C., KOZUR H. W. and MOHTAT-AGHAI P. (2004) - Dzhulfian to lowermost Triassic $\delta^{13} \mathrm{C}$ record at the Permian/Triassic boundary section at Shahreza, Central Iran. Hallesches Jb. Geowiss. Bh., 18: 73-78.

KORTE C., JASPER T. T., KOZUR H. W. and VEIZER J. (2005) $-\delta^{18} \mathrm{O}$ and $\delta^{13} \mathrm{C}$ of Permian brachiopods: a record of seawater evolution and continental glaciation. Palaeogeogr. Palaeoclimatol. Palaeoecol., 224: 333-351.

KORTE C., PANDE P., KALIA P., KOZUR H. W., JOACHIMSKI M. M. and OBERHÄNSLI H. (2010) - Massive volcanism at the Permian-Triassic boundary and its impact on the isotopic composition of the ocean and atmosphere. J. Asian Earth Sc., 37: 293-311.

KOTARBA M. J., PERYT T. M., KOSAKOWSKI P. and WIECCŁAW D. (2006) - Organic geochemistry, depositional history and hydrocarbon generation modelling of the Upper Permian Kupferschiefer and Zechstein Limestone strata in south-west Poland. Mar. Petrol. Geol., 23: 371-386.

KOZUR H. (1998) - Permian conodont biochronology. Progress and problems. Proc. R. Soc. Victoria, 110: 197-220.

LANGFORD F. F. and BLANC-VALLERON M. M. (1990) - Interpreting Rock-Eval pyrolysis data using graphs of pyrolizable hydrocarbons vs. total organic carbon. AAPG Bull., 74: 799-804.

LEGLER B. and SCHNEIDER J. W. (2008) - Marine ingressions into the Middle/Late Permian saline lake of the Southern Permian Basin (Rotliegend, Northern Germany) possibly linked to sea-level highstands in the Arctic rift system. Palaeogeogr. Palaeoclimatol. Palaeoecol., 267: 102-114.

MAGARITZ M. and PERYT T. M. (1994) - Mixed evaporative and meteoric water dolomitization; isotope study of the Zechstein Limestone (Upper Permian), southwestern Poland. Sediment. Geol., 92: 257-272.

MAGARITZ M. and SCHULZE K.-H. (1980) - Carbon isotope anomaly of the Permian period. Contr. Sediment., 9: 269-277.

MAGARITZ M. and TURNER P. (1982) - Carbon cycle changes of the Zechstein Sea: isotopic transition zone in the Marl Slate. Nature, 297: 389-390.

MAGARITZ M., TURNER P. and KÄDING K. C. (1981) - Carbon isotopic change at the base of the Upper Permian Zechstein sequence. Geol. J., 16: 243-254.

MAGARITZ M., ANDERSON R. Y., HOLSER W. T., SALTZMAN E. S. and GARBER J. (1983) - Isotope shifts in the Late Permian of the Delaware Basin, Texas, precisely timed by varved sediments. Earth Planet. Sc. Lett., 66: 111-124.

MAROWSKY G. (1969) - Schwefel-, Kohlenstoff- und Sauerstoff-Isotopenuntersuchungen am Kupferschiefer als Beitrag zur genetischen Deutung. Contr. Miner. Petrol., 22: 290-334.

McCREA J. M. (1950) - On the isotopic geochemistry of carbonates and a paleotemperature scale. J. Chem. Phys., 18: 849-857.

MEI S. and HENDERSON C. (2001) - Evolution of Permian conodont provincialism and its significance in global correlation and paleoclimate implication. Palaeogeogr. Palaeoclimatol. Palaeoecol., 170: $237-260$.

MENNING M. (1995) - A numerical time scale for the Permian and Triassic periods: an integrative time analysis. In: The Permian of Northern Pangea (eds. P. A. Scholle, T. M. Peryt and D. S. Ulmer-Scholle): 77-97. Springer, Berlin.

MENNING M. (2001) - A Permian Time Scale 2000 and correlation of marine and continental sequences using the Illawarra Reversal (265 Ma). Natura Bresciana, Ann. Mus. Civ. Sc. Nat., Monografia, 25: 355-362.

MENNING M., GAST R., HAGDORN H., KÄDING K.-C., SIMON T., SZURLIES M. and NITSCH E. (2005) - Zeitskala für Perm und Trias in der Stratigraphischen Tabelle von Deutschland 2002, zyklostratigraphische Kalibrierung der höheren Dyas und Germanischen Trias und das Alter der Stufen Roadium bis Rhaetium 2005. Newslett. Stratigr., 41: 174-210.

METCALFE I., FOSTER C. B., AFONIN S. A., NICOLL R. S., MUNDIL R., WANG X. and LUCAS S. G. (2009) - Stratigraphy, biostratigraphy and $\mathrm{C}$-isotopes of the Permian-Triassic non-marine sequence at Dalongkou and Lucaogou, Xinjiang Province, China. J. Asian Earth Sc., 36: 503-520

NOBLE P. J., POULSON S. R., MALDONADO A. L., LAMBERT L. L., WARDLAW B. R., NESTELL M. K. and BELL G. L. (2009) - Latest Guadalupian carbon isotope record from the Reef Trail Member of the Bell Canyon Formation, West Texas, USA. Geol. Soc. Am. Abstracts with Programs, 41 (2): 28.

OEHLERT A. M., LAMB-WOZNIAK K. A., DEVLIN Q. B., MACKENZIE G. J., REIJMER J. J. G. and SWART P. K. (2012)-The stable carbon isotopic composition of organic material in platform derived sediments: implications for reconstructing the global carbon cycle. Sedimentology, 59: 319-335

OELSNER O. (1959) - Bemerkungen zur Herkunft der Metalle im Kupferschiefer. Freiberger Forschungsh., C56: 106-113.

OSZCZEPALSKI S. (1989) - Kupferschiefer in southwestern Poland: sedimentary environments, metal zoning, and ore controls. Geol. Ass. Can. Spec. Pap., 36: 571-600.

OSZCZEPALSKI S. and RYDZEWSKI A. (1987) - Paleogeography and sedimentary model of the Kupferschiefer in Poland. Lect. Notes Earth Sc., 10: 189-205.

PAŠAVA J., OSZCZEPALSKI S. and DU A. (2010) - Re-Os age of non-mineralized black shale from the Kupferschiefer, Poland, and implications for metal enrichment. Min. Deposita, 45: 189-199.

PAUL J. (1982) - Types of stratification in the Kupferschiefer. In: Cyclic and Event Stratification (eds. G. Einsele and A. Seilacher): 476-481. Springer, Berlin.

PERYT T. M. (1984) - Sedimentation and early diagenesis of the Zechstein Limestone in Western Poland (in Polish with English summary). Prace Inst. Geol., 109: 1-70. 
PERYT T. M. and MAGARITZ M. (1990) - Genesis of evaporite-associated platform dolomite: case study of the Main Dolomite (Zechstein, Upper Permian), Leba elevation, northern Poland. Sedimentology, 37: 745-761.

PERYT T. M. and PERYT D. (1975) - Association of sessile tubular foraminifera and schizophytic algae. Geol. Mag., 112: 612-614.

PERYT T. M. and PERYT D. (2012) - Geochemical and foraminiferal records of environmental changes during the Zechstein Limestone (Lopingian) deposition in Northern Poland. Geol. Quart., 56 (1): $187-198$.

PERYT T. M. and SCHOLLE P. A. (1996) - Regional setting and role of meteoric water in dolomite formation and diagenesis in an evaporite basin: studies in the Zechstein (Permian) deposits of Poland. Sedimentology, 43: 1005-1023.

PERYT T. M., PIERRE C. and GRYNIV S. P. (1998) - Origin of polyhalite deposits in the Zechstein (Upper Permian) Zdrada Platform (northern Poland). Sedimentology, 45: 565-578.

PERYT T. M., GELUK M. C., MATHIESEN A., PAUL J. and SMITH K. $(2010 a)-$ Zechstein. In: Petroleum Geological Atlas of the Southern Permian Basin Area (eds. J. C. Doornenbal and A. G. Stevenson): 123-147. EAGE Publications b.v. (Houten).

PERYT T. M., HAŁAS S. and HRYNIV S. P. (2010b) - Sulfur and oxygen isotope signatures of Late Permian Zechstein anhydrites, West Poland: seawater evolution and diagenetic constraints. Geol. Quart., 54 (4): 387-399.

RASMUSSEN J. A., PIASECKI S., STEMMERIK L. and STOUGE S. (1990) - Late Permian conodonts from central East Greenland. N. Jb. Geol. Paläont. Abh., 178: 309-324.

RENTZSCH J. (1965) - Die feinstratigraphisch-lithologische Flözlagenparallelisierung im Kupferschiefer am Südrand des norddeutschen Zechsteinbeckens. Z. angew. Geol., 11 (1): 11-14.

RICHOZ S., KRYSTYN L., BAUD A., BRANDNER R., HORACEK M. and MOHTAT-AGHAI P. (2010) - Permian-Triassic boundary interval in the Middle East (Iran and N. Oman): progressive environmental change from detailed carbonate carbon isotope marine curve and sedimentary evolution. J. Asian Earth Sc., 39: 236-253.

ROSS C. A. and ROSS J. R. P. (1995) - Permian sequence stratigraphy. In: The Permian of Northern Pangea (eds. P. A. Scholle, T. M. Peryt and D. S. Ulmer-Scholle), 1: 98-123. Springer, Berlin.

SCHOLLE P. A. (1995) - Carbon and sulphur isotope stratigraphy of the Permian and adjacent intervals. In: The Permian of Northern Pangea (eds. P. A. Scholle, T. M. Peryt and D. S. Ulmer-Scholle), 1: 133-149. Springer, Berlin.

SŁOWAKIEWICZ M., KIERSNOWSKI H. and WAGNER R. (2009) Correlation of the Upper Permian marine and terrestrial sedimentary sequences in Polish, German, and USA Western Interior Basins with reference to global time markers. Palaeoworld, 18: 193-211.

SMITH D. B. (1979) - Rapid marine transgressions and regressions of the Upper Permian Zechstein Sea. J. Geol. Soc. London, 136: 155-156.
SMITH D. B. (1994) - Geology of the country around Sunderland. Memoir of the British Geological Survey, sheet 21 (England and Wales). London.

SØRENSEN A., HÅKANSSON E. and STEMMERIK L. (2007) - Faunal migration into the Late Permian Zechstein Basin - evidence from bryozoan palaeobiogeography. Palaeogeogr. Palaeoclimatol. Palaeoecol., 251: 198-209.

SUVEIZDIS P., ed. (1975) - Permian deposits of Baltic area (stratigraphy and fauna) (in Russian). Transactions, 29, Mintis, Vilnius.

SWART P. K. (2008) - Global synchronous changes in the carbon isotopic composition of carbonate sediments unrelated to changes in the global carbon cycle. PNAS, 105 (37): 13741-13745.

SWEENEY M., TURNER P. and VAUGHAN D. J. (1987) - The Marl Slate: a model for the precipitation of calcite, dolomite and sulphides in a newly formed anoxic sea. Sedimentology, 34: 31-48.

SWEET W. C. (1976) - Conodonts from the Permian-Triassic boundary beds at Kap Stosch, East Greenland. Medd. Gørnland, 197 (5): 51-54.

SWIFT A. (1995) - Conodonts from the Late Permian and Late Triassic of Britain. Monogr. Palaeontogr. Soc. Lond., 98 (147): 1-80.

SWIFT A. and ALDRIDGE R. J. (1986) - Conodonts of the Permian system from Great Britain. In: A Stratigraphical Index of Conodonts (eds. A. C. Higgins and R. C. Austin): 228-236. Ellis Horwood, Chichester.

SZANIAWSKI H. (1969) - Conodonts of the Upper Permian of Poland. Acta Palaeont. Pol., 14 (2): 325-341.

TURNER P. and MAGARITZ M. (1986) - Chemical and isotopic studies of a core of Marl Slate from NE England: influence of freshwater influx into the Zechstein Sea. Geol. Soc. Spec. Publ., 22: 19-29.

UNDERWOOD C. J., CROWLEY S. F., MARSHALL J. D. and BRENCHLEY P. J. (1997) - High-resolution carbon isotope stratigraphy of the basal Silurian Stratotype (Dob's Linn, Scotland) and its global correlation. J. Geol. Soc. London, 154: 709-718.

WAGNER R. (2001) - Występowanie fauny i flory w osadach permu polskiego. In: Budowa geologiczna Polski, tom III, Atlas skamieniałości przewodnich i charakterystycznych, część 1c - z. 3 (eds. M. Pajchlowa and R. Wagner): 16-18. Państw. Inst. Geol., Warszawa.

WAGNER R., ed. (2009) - Suplement do tabeli stratygraficznej Polski. Państw. Inst. Geol., Warszawa.

WANG W., CAO C.-Q. and WANG Y. (2004) - The carbon isotope excursion on GSSP candidate section of Lopingian-Guadalupian boundary. Earth Planet. Sc. Lett., 220: 57-67.

WARDLAW B. R. and MEI S. (1999) - Refined conodont biostratigraphy of the Permian and lowest Triassic of the Salt and Khizor ranges, Pakistan. In: Proceedings of the International Conference on Pangea and the Paleozoic-Mesozoic Transition (eds. H. Yin and J. Tong): 154-156. China University of Geosciences Press, Wuhan.

ZHOU Z., GLENISTER B. F., FURNISH W. M. and SPINOSA C. (1996)Multi-episodal extinction and ecological differentiation of Permian ammonoids. Permophiles, 29: 52-62. 